\title{
The Genus Phymatolithon in the Gulf of Maine
}

\author{
by \\ WALTER H. AdeY \\ Department of Botany \\ University of Michigan \\ Ann Arbor, Michigan, U.S.A. ${ }^{1}$
}

\section{INTRODUCTION}

The shallow coastal waters in the area extending from Long Island Sound to Cape Roseway in southern Nova Scotia were surveyed in this study. Collections were made at all seasons of the year, largely by SCUBA diving, the primary sublittoral stations being indicated in fig. 8. The investigation as a whole included all of the rock-encrusting crustose corallines in the region and is based on about 2500 specimens of coralline covered rock and shell from over 100 localities. Microtome and ground sections of about 800 individual plants were prepared for the anatomical work.

The genera Phymatolithon and Clathromorphum were first described by FosLIE (1898a), being based on Millepora polymorpha L. and on Lithothamnium compactum KJELLMAN respectively. The descriptions were later reworded by FosLIE (1900), but the essentials were unchanged. These genera were separated from Lithothamnium because of their immersed conceptacles. However, there are all degrees of conceptacle immersion among the species of Lithothamnium, and even within a single species the character can be somewhat variable. Many authors have not accepted this as a valid distinction:

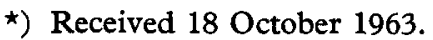

1) Now at Colorado School of Mines, Golden, Colorado, U.S.A. The necessary field work for this study was made possible through the generous support of: The American Petroleum Institute, The Geological Society of America, the ONR (through the Department of Geology and Geophysics, Massachusetts Institute of Technology) and the Woods Hole Oceanographie Institution (Contr. No. 1500). 
Lemoine, 1911; Rosenvinge, 1917; Suneson, 1943; Hamel \& LEMOINE, 1953; KYLIN, 1956.

The difference between the two genera in the original descriptions lays in the early appearance in surface view of a raised white spot over the sporangial conceptacles of Clathromorphum, a feature not described for Phymatolithon. An initial elevation, according to FosLIE, appeared in the carposporangial conceptacles of Phymatolithon, but no carposporangial conceptacles of Clathromorphum were known at that time. As will be shown below, degenerating tissue, i.e., white spots, occurs over the young conceptacles of members of both genera. In 1905, FosLIE, without further description, considered Clathromorphum as a subgenus of Phymatolithon. Later, as Clathromorphum compactum, FosLIE (1908) again used this genus name, largely on the basis of the presence between the larger perithallial cells of small, oblique-walled cells not found in Phymatolithon. These small cells, which were not illustrated, have not been found in the writer's material and to his knowledge have not been seen by other workers. However, distinctive end walls do appear in species of this genus and in a ground section could be mistaken for small cells. The two genera were kept separate, without further descriptions, in his posthumous 1929 work.

Thus, neither of these genera was originally studied or described sufficiently to warrant separation from Lithothamnium, and the species involved have been variously treated in papers since FosLIE's original description.

The only really new information on Clathromorphum is a description of the very rare male and female conceptacles by MASAKI \& TOKIDA (1961). Primarily on the basis of differences between the spermatangial conceptacles in C. compactum and Phymatolithon polymorphum (as described by SUNESON, 1943), they conclude that 'the validity of recognition of Clathromorphum as an independent genus is now more fully established'.

Even though Millepora polymorpha $\mathrm{L}$. was the type for the genus Phymatolithon, HEYDRICH (1900) created the new genus Eleutherospora, based on the same species. He distinguished this genus primarily by pecularities in the procarp and carposporangia which have not been generally acceptable to later workers. He apparently did not find the 'conceptacle caps' noted by a number of other authors (discussed below) and in the same paper separated plants of Lithothamnium (Phymatolithon) laevigatum bearing such caps into a new species, L. emboloides. KyLIN (1956) did not recognize Clathromorphum and separated Phymatolithon from Lithothamnium primarily on the basis of an 'up-and-down-bending' hypothallium.

The writer, in his study of the crustose corallines of the Gulf of 
Maine, has found that the genera Clathromorphum and Phymatolithon, on the basis of the anatomy and cytology of the vegetative thalli and the position of the conceptacle primordia, are indeed distinct. On the same basis, these genera are distinct from the branching members of Lithothamnium. All of the members of Clathromorphum studied (C. compactum and C. circumscriptum from the Gulf of Maine and $C$. loculosum from the northern Pacific) possess a well-defined, deeply-sunken intercalary meristem which produces tissue above and below. Most of the cell enlargement in these species occurs in the initials prior to their being cut off, little elongation occurring in the derivatives. The tissue overlying the meristem is photosynthetic and ranges from about $1-16$ cells thick, largely depending on the species, the age of the plant and distance from the growing margin. It is apparently homologous with a series of cover cells. (The term 'epithallium' is here applied only to the tissue that is produced above the intercalary meristem.) Reproductive primordia develop in the intercalary meristem, and the immersed nature of the mature conceptacles is partly a result of the position of this meristem. In addition, the calcified cell walls of Clathromorphum species are peculiar, being made up of distinct lateral and end portions, while the structure of the pits is somewhat different from that found in Phymatolithon and Lithothamnium. Also, the male conceptacles are structurally like the asexual conceptacles, and the spermatangial filaments are quite simple as compared to the dendroid filaments of $P h y$ matolithon and Lithothamnium. The species of Clathromorphum will be the subject of a later paper on the Gulf of Maine crustose corallines.

Species of Phymatolithon have an intercalary meristem which is essentially surficial. However, it does not form a definite layer, and most of the cell elongation occurs in derivatives of this meristem after they are cut off from the initials. An overlying non-photosynthetic epithallium is produced, but is generally only one cell layer thick (cover cells), and often sloughing-off of these cells occurs at such a rate that there is no epithallium retained over large areas. The conceptacle primordia, however, are not produced by the perithallial meristem as in Clathromorphum, but rather, are developed 'adventitiously' deep in the perithallium. These features are discussed in detail below.

The branching members of Lithothamnium studied, like the Phymatolithon species, have a nearly surficial intercalary meristem with a thin non-photosynthetic epithallium. The epithallial cells, however, which generally form a single layer (cover cells), are laterally and basally thick-walled, rectangular in vertical section and in general morphologically quite distinct from their counterparts in Clathromorphum and Phymatolithon. Although the branching members of 
Lithothamnium are otherwise cytologically much like Phymatolithon, the conceptacle primordia are not produced adventitiously deep in the perithallium, but rather develop directly from the intercalary meristem. These species will also be treated in detail in a paper to be published later.

TAYLOR (1962) listed four species of Phymatolithon from the region of this study. Two of these, Ph. compactum and Ph. evanescens, should be placed in Clathromorphum. Ph. polymorphum has not been found in the Gulf of Maine during this study and since it was a 'catch-all' species in earlier works (KJELLMAN 1883), the references to it are doubtful. Foslie (1905), for example, stated that Lithothamnium polymorphum of FARLOW (1881) is a form of C. circumscriptum. Two of the Phycotheca Boreali-Americana specimens called $L$. polymorphum have been examined and both are very likely $P h$. laevigatum. KJELLMAN (1883) reported L. polymorphum from Baffin Bay, but LuND (1959) failed to describe the species from east Greenland, and Howe (1927) did not mention its occurrence in Hudson Bay. In the Gulf of Maine, Ph. laevigatum is an important species of crustose coralline. It extends both north and south of the region. In the central and eastern part of the Gulf Ph. rugulosum is abundant; it does not extend south of Cape Cod, and its extension northeastward is unknown.

\section{TAXONOMIC SYNopsis}

\section{Phymatolithon foslie, emend.}

Plants crustose; hypothallium running sub-parallel to the substrate and turning up to form the perithallium, short dead-ended filaments turning down to the substrate, thin epithallium ( $0-3$ cells), meristem near surface, perithallial cells gradually lengthening as they are buried; cell walls not formed of lateral and end units; all conceptacle primordia formed adventitiously from cells sunken in the perithallium, overlying perithallium raised and cut-off as disks while conceptacles develop, the mature conceptacles generally sunken; asexual sporangia with thick cap walls (i.e., conceptacles with many pores); male and female conceptacle roofs formed by overgrowing of lateral perithallial tissue; spermatangia borne in dendroid clusters completely clothing the conceptacle walls.

Phymatolithon laevigatum (FosL.) FosL.

Foslie, 1898b, p. 8, 1900, p. 10; BatTers, 1902, p. 98; Borgesen, 1902, p. 400; Foslie, 1905, p. 79; Detoni, 1905, p. 1725; KYLIN, 1907, p. 198; RosenVINGE, 1917, p. 228; HOWE, 1927, p. 26; FOSLIE, 1929, p. 47; TAYLOR, 1937, p. 261, 1962, p. 244.

Lithothamnium laevigatum FosL.

FosLIE, 1894, pp. 167-170; HeYdrich, 1897a, p. 55, 1897b, p. 413, 1900. p. 76. 


\section{Lithothamnium emboloides HEYDR.}

HEYDRICH, 1900, p. 74.

Phymatolithon emboloides (HEYDR.) DE TONI.

DE ToNI, 1905, p. 1726.

Lithothamnium polymorphum f. papillatum FosL.

Phycotheca Boreali-Americana, LXIX, from herb. W. R. TAYLOR no. 7487, and herb. MICH.

Plants crustose, $50 \mu$ to $0.75 \mathrm{~mm}$ thick; the surface with very low, sometimes white-edged ridges and mounds, otherwise smooth; yellow-pink-violet; hypothallium $2-5$ cells, $13-43 \mu$ thick, cells $8.5-31.0 \mu$ long, $3.0-8.5 \mu$ diam.; perithallial cells $0.5-10.0 \mu$ long, $3.5-11.5 \mu$ diam. (cell lumen), meristem nearly surficial; epithallium generally $1-3$ cells thick; all conceptacles developed from sunken primordium; sporangial conceptacles producing bispores, rarely tetraspores, crowded over the whole surface except the margin, the roof at the same level as the surrounding thallus at maturity, with a marked elevated border, the roof $98-230 \mu$ diam. with $20-88$ pores, the conceptacle cavity $170-350 \mu$ diam., $72-150 \mu$ high; spermatangial conceptacles sunken with a slightly projecting orifice, $130-250 \mu$ diam., roof developed by overgrowing of lateral perithallium, spermatangia in dendroid clusters clothing the entire interior of the conceptacle; carpogonial conceptacles unknown; distribution, North Atlantic, in this study Long Island Sound to Cape Roseway, Nova Scotia.

Phymatolithon rugulosum sp. nov.

Plantae crustosae $50 \mu$ to $4 \mathrm{~mm}$ crass.; superficies rugis tumulisque tenuissimis oram albam habentibus, saepe praedita; hypothalium $17-50 \mu$ crass.; e $2-8$ cellulis $8-31 \mu$ long., $3-8 \mu$ diam. constans; cellulae perithallii $0.5-$ $3.0 \mu$ long., $2.5-8.5 \mu$ diam. (lumine cellulae metato); epithallium e nulla, vel una vel duabus cellulis constans; conceptacula sporangialia biosporas, raro tetrasporas efficientia, matura tecto toto immerso, lamina pororum $55-122 \mu$ diam., 12-44 poros per oram elevatam circumdatos, habens; cavo conceptacli $120-240 \mu$ diam., $33-100 \mu$ alt.; conceptacula spermatangialia immersa 85-200 $\mu$ diam.; conceptacula carpogonialia immersa $105-155 \mu$ diam. Holotypos W. H. ADEY 61-41A-3 in loco Merchant Is., Knox Co., East Penobscot Bay, Maine dicto, 3-5 metorum altitudine repertus, $2 \mathrm{~m}$. Nov. 1961, in herbario Universitatis Michiganesis dispositus.

Plants crustose, $50 \mu$ to $4 \mathrm{~mm}$ thick; the surface with very fine, low, sometimes white-edged ridges and mounds, otherwise smooth; pink-violet; hypothallium $2-8$ cells, $17-50 \mu$ thick with cells $8-31 \mu$ long, $3-8 \mu$ diam.; perithallial cells $0.5-13 \mu$ long, $2.5-8.5 \mu$ diam. (cell lumen), meristem surficial or nearly so; epithallium present marginally, mostly sloughing off; all conceptacles developed from a sunken primordium; sporangial conceptacles producing bispores, rarely tetraspores, crowded over the whole surface except the margin, roof with a raised rim below the level of the surrounding thallus at maturity, pore plate $55-122 \mu$ diam. with $12-44$ pores, conceptacle cavity $120-240 \mu$ diam., 33-100 $\mu$ high; spermatangial conceptacles sunken, with slightly projecting orifice, $85-200 \mu$ diam., roof formed by overgrowing of the lateral perithallium, spermatangia in dendroid clusters clothing the entire interior of the conceptacle; carpogonial conceptacles developed as spermatangial, 105$155 \mu$ diam., procarp consisting of a supporting auxiliary cell bearing two sterile cells and a two-celled carpogonial filament, after fertilization(s) carpogonia fusing with hypogynous cells and then auxiliary cells, auxiliary cells irregularly fusing with each other, (further development?). 
Holotype: southwest Merchant Island, East Penobscot Bay, Maine, 3-5 meters below mean low water. Coll. ADEY no. $61-41 \mathrm{~A}-3$ in herb. $\mathrm{MICH}$. November 2, 1961; known distribution Gulf of Maine, Massachusetts Bay to Cape Roseway, Nova Scotia.

\section{VEGETATIVE ANATOMY}

Both Phymatolithon laevigatum and Ph. rugulosum are crustose species. Major surface irregularities when present are a result of growing over an uneven surface. However, both species have distinctive minor surface patterns that usually allow them to be recognized even in the absence of reproductive structures, once some familiarity with them is attained. In general, vegetative $P$ h. rugulosum has a very fine pattern of mounds or short sub-parallel ridges, the rims oftentimes being white on the general red-violet surface (Figs. 15-17). Ph. laevigatum, with essentially the same color, also has mounds and ridges, but these are mostly somewhat larger, and there are fewer of them (Figs. 21-23). The distinction is usually most strongly marked in young plants; older specimens, especially those in the process of producing reproductive structures, may lack these ridges (Figs. 18, 24).

\section{TABLE I}

Comparison of hypothallium in Phymatolithon rugulosum and Ph. laevigatum (Measurements of hypothallia developed on level substrate).

Species

Depth

Cell

$(\mu)$

Cell

Diam.

( $\mu$ )

Hypothallium Thickness (

\begin{tabular}{|c|c|}
\hline \multicolumn{2}{|c|}{$\begin{array}{l}\text { Ph. rugulosum } \\
49 \text { cells } \\
14 \text { plants } \\
9 \text { stations }\end{array}$} \\
\hline$<6 \mathrm{~m}$. & $>6 \mathrm{~m}$ \\
\hline 28 & 31 \\
\hline 16.5 & 18 \\
\hline 8 & 10 \\
\hline 7 & 7 \\
\hline 4.5 & 5 \\
\hline 3 & 3 \\
\hline 50 & 28 \\
\hline 37 & 23 \\
\hline 20 & 17 \\
\hline
\end{tabular}

These species possess a thin, multi-layered hypothallium (Figs' 28,31 ). The cells of this tissue extend approximately parallel to the substrate in the direction of growth and are usually slightly angled either downward or upward. Comparative data for the hypothallium are presented in Table I. In both cases, the data have been derived 
from plants scattered over the respective depth and geographic ranges of each species in the area. The data for both species are separated according to the depth from which the plants were taken. In both species, there is a general increase of cell size with depth. The differences in mean diameter with depth for Ph. rugulosum and length for $P h$. laevigatum, using the t-distribution, are highly significant, while difference in diameter with depth for $P h$. laevigatum shows a probability of only .08 . (The $0.5 \mu$ mean diameter difference with depth for Ph. rugulosum is small as a result of rounding, the actual values used for calculating significance being $4.3 \mu$ and $5.2 \mu$ ). The length differences in Ph. rugulosum are not significant. On the other hand, JoHNSON (1961), suggests a decrease in hypothallial cell length with depth in Ph. polymorphum and Lithothamnium lenormandi. Especially because of its possible paleoecological significance, the matter is in need of further detailed study for many species.

The differences in hypothallial cell length between the two species, for shallow and deep water, are not significant. However, $P h$. laevigatum has hypothallial cell diameters which are larger than $P h$. rugulosum for both depth ranges. In each case, these are highly significant. This condition is paralleled in the perithallium, see below.

The situation with regard to the thickness of the hypothallium is somewhat confusing. In Ph. laevigatum, in parallel with the increase of hypothallial cell size with depth, the thickness also shows a significant increase. However, in Ph. rugulosum, the reverse is true. In shallow water, $P h$. rugulosum has a significantly thicker hypothallium than Ph. laevigatum. The difference in the means for the plants taken from deeper water is not significant. Both species contrast strongly with $\mathrm{Ph}$. polymorphum as described and illustrated by SunEson (1943). Here, the hypothallium is about $150 \mu$ thick and consists of markedly up- and down-bending filaments. KYLIN (1956) used this latter feature as the chief characteristic of the genus. However, in the eight species of Lithothamnium, Phymatolithon and Clathromorphum with which the writer has worked, including $P h$. laevegatum and $P h$. rugulosum, downgrowing, dead-ended filaments are always present, although they are generally not conspicuous.

The thickness of the perithallium depends upon the age of the plant, and in both species, upward growth can apparently be continuous. Total thickness of the plants near the growing margins is approximately $50-70 \mu$ while the maximum thickness of individual plants seen in this study approximated $4 \mathrm{~mm}$. in Ph. rugulosum and $0.75 \mathrm{~mm}$ in $P h$. laevigatum. Overgrowing of either of these species over other plants of the same or different species does occur, but it is not a conspicuous feature.

The asexual conceptacles in these species are not normally over- 


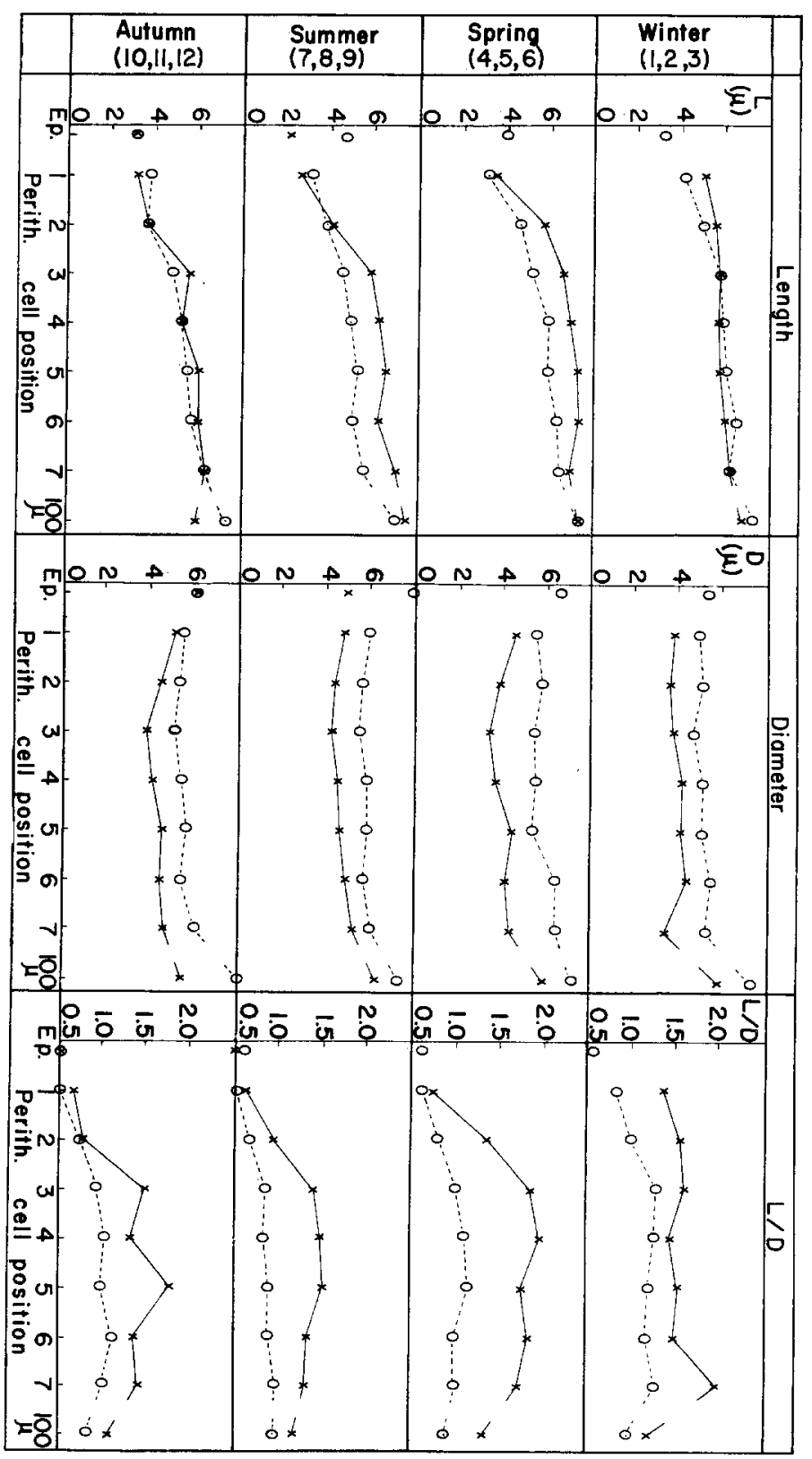

Fig. 1.

grown and buried by vegetative tissue. However, the new tissue which grows in basally to fill them is generally distinct even after deep burial. On the basis of the positions of these old conceptacles, 
and considering the yearly reproductive cycles (see below), it is possible to compute an upward growth rate in these two species of from $50-200 \mu$ per year. The variation probably results primarily from variation in depth of growth and the presence of overlying algae. The rates here compare favorably with more accurately determined growth rates of $100-500 \mu$ per year in the commonly thicker Clathromorphum compactum. The mean diameter, length and lengthdiameter $(\mathrm{L} / \mathrm{D})$ ratio of the upper perithallial cells of $P h$. rugulosum and $P h$. laevigatum are plotted as a function of position in the thallus and season in fig. 1 . The numbers $1-7$ refer to cell position below the cover cell. Measurements of three cells were taken in each plant at about a depth of $100 \mu$ from the surface; combined, these are included below number 7 . The data for Ph. rugulosum (x) were derived from 61 cell rows in 31 plants from 23 stations, the $P$ h. laevigatum data (o) were taken from 52 cell rows in 48 plants from 29 stations. A similar series of measurements from single plants of both species taken in the summer shows curves which are not significantly different from these with regard to either length or diameter. Also, in each case, the variability (i.e., the coefficients of variation) in both dimensions, as tested by Chi-square, is not significantly lower in single specimens than it is in the whole sample.

The upper parts of the young, growing margins of both $P h$. laevigatum and $P h$. rugulosum usually possess well-defined cover cells (epithallium), cells with thin walls and lacking chromatophores (Figs. 27, 30). In Ph. rugulosum, within a few hundred microns of the growing margin and oftentimes much less, these are sloughed off. Similar cells, or more often cells with thicker walls similar to the underlying perithallial cells but without chromatophores, are apparently then formed, but either they are formed at a very slow rate or are also rapidly sloughed off. Only 8 percent of the rows measured in Ph. rugulosum contained such cells. On the other hand, in $P h$. laevigatum the cover cells are long-lasting; sometimes a second or even a third layer of similar cells is formed beneath the first before cleavage occurs (Fig. 34). Thus, in contrast, 38 percent of the rows of $P h$. laevigatum measured were topped by cover cells.

In the genus Clathromorphum and in the branching members of Lithothamnium there is little difficulty in determining the position of the perithallial meristem. In both cases there is a definite row of large cells, cytologically distinct, in which division stages are found, such stages not being seen elsewhere. Also, in both cases, the cells in the overlying tissue are cytologically distinct from those in the underlying tissue. The large size of the meristem cells in Clathromorphum is a result of a peculiar form of growth in which cell enlargement occurs before a cell is cut off from its mother cell, very 
little growth occurring thereafter. There is little doubt about the intercalary nature of the meristem in either of these cases since in Clathromorphum the photosynthetic epithallium, or overlying tissue, continuously increases in thickness with distance from the growing margin, while in the branching members of Lithothamnium, the quite distinctive cover cells are sometimes found two or even three layers thick.

In all of these genera, the outermost cover cells, regardless of the thickness of the epithallium, are generally in various stages of degeneration. It seems likely that the intercalary meristem continuously produces cells upward, and the thickness of the epithallium is maintained by a balance between production in the meristem and sloughing off at the surface. Such sloughing off could perform an important function in keeping the surface of the plant clear of other sedentary organisms.

In Phymatolithon laevigatum and Ph. rugulosum there is no definite layer of large cells. The cells immediately below the cover cells, if there are any, or in some cases the second or rarely third cells, commonly show cell divisions (i.e., telophase or prophase stages), and such stages do not generally occur at greater depths in the thallus. In these species, a meristem cell, when it divides, cleaves tangentially into two essentially equal halves.

As can be seen from the means of cell length plotted in fig. 1, for both species, there is a general increase of perithallial cell length with depth in the thallus. Since the walls of cells below the epithallium are calcified and there are no apparent breaks in the calcification, the calcite must be continuously deposited in the walls along with other wall materials as the cells enlarge. (This contrasts strongly with Clathromorphum, where there is a break in the calcification in the meristem and little growth elsewhere.) Most of the increase in cell length is apparently relatively rapid, occurring while an additional cell or two is being divided off in the meristem. In both species, the mean length of cells one and two is significantly larger in the winter than in the summer. This probably indicates a low rate of division relative to enlargement rate during this period. In some cases, however, it would seem to be a result of a downward 'migration' of the meristem position along with a general sloughing off of surface cells accompanied by a low rate of division. During the spring and summer the central upper perithallial cells, that is, cells two through seven, are significantly longer in Ph. rugulosum than Ph. laevigatum, but there is little difference in the fall and winter.

The mean cell lumen diameters of the perithallial cells of $P h$. laevigatum are significantly larger in almost all cases than those measured in $P h$. rugulosum. In both cases there is a significant 


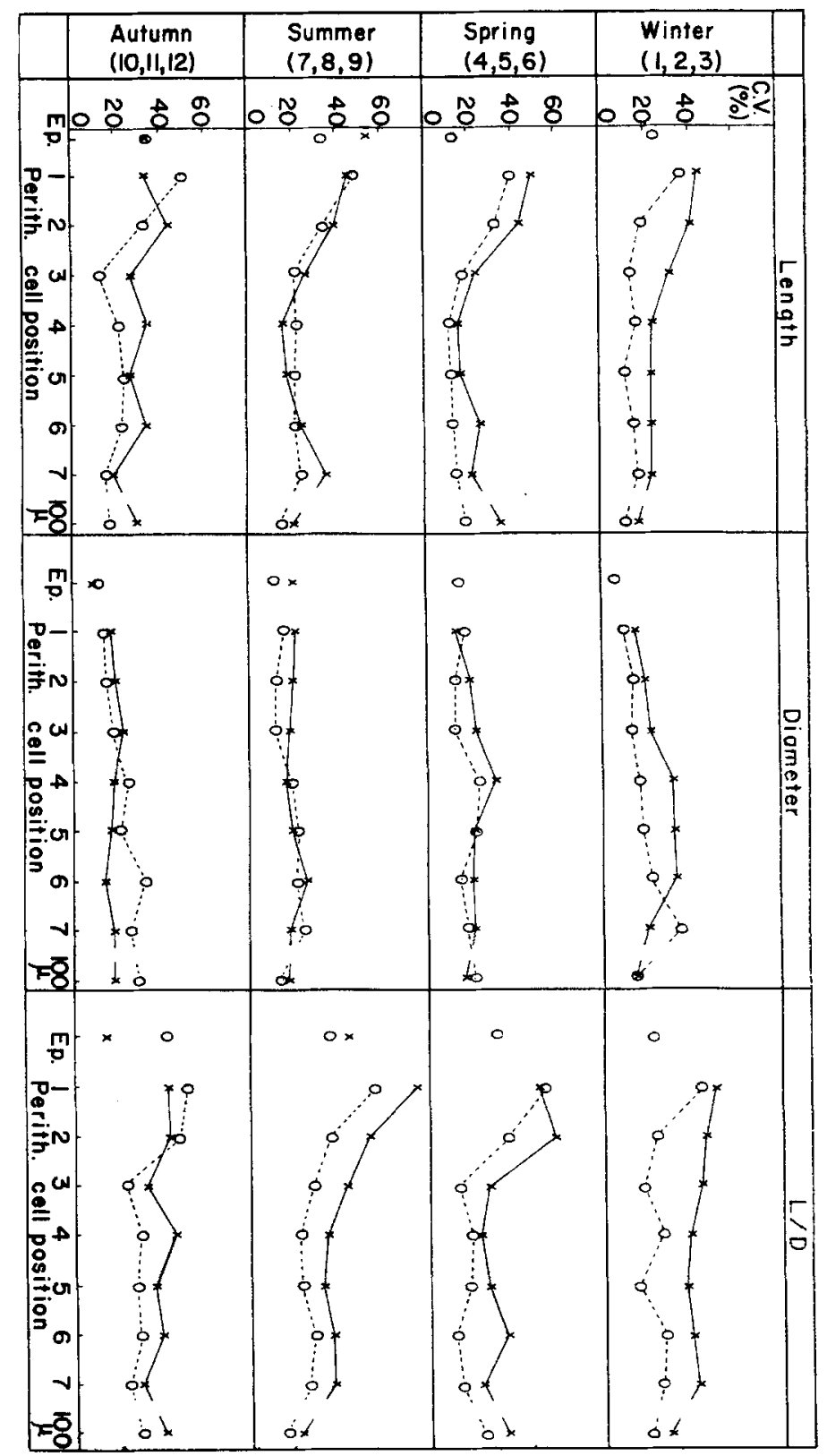

Fig. 2.

increase in lumen diameter below cell seven. This may result from a removal of wall material and a decrease in wall thickness, though it could be an effect of fixation and should be carefully checked on 
many ground sections. Although there are no consistent differences in mean cell length between the two species at $100 \mu$ depth in the perithallium, the mean diameters of these cells in $\mathrm{Ph}$. laevigatum are consistently larger than those in Ph. rugulosum.

A combining of the data for cell length and cell diameter into a length over diameter ratio shows most strikingly the differences in the upper perithallial tissue between the two species. The more elongate nature of these cells in Ph. rugulosum is apparent at all seasons, though it is most marked during the spring and summer.

The coefficients of variation for the data in fig. 1 are presented in fig. 2. The length data could be compared to a model of a meristem just below the cover cells, in which the meristem initial itself rapidly enlarges and divides while the cell cut off below gradually increases in length with burial, rapidly at first and thereafter more slowly. Here one would expect a coefficient of variation curve for length that would be a maximum in cell one and would decrease downward, as the rate of elongation decreased, approaching asymptomically a minimal level of variation with increasing depth. In general this is borne out in the plotted curves for both species. The rising tendency of the coefficient of variation for length in the lower part of the upper perithallium or in the deeper perithallium as well as the general irregularity of the fall curve for $P h$. rugulosum is unexplained. The coefficients of variation for diameter for both species are mostly narrowly confined and change little with depth. The winter curves are somewhat anomalous, however.

It would be expected that the coefficient of variation of the ratio of length over diameter would tend not to show variation in overall cell size and would therefore show the effects of tangential division more clearly. During the probable periods of maximum growth in the spring and summer, the expected curves appear. Again, the winter and fall curves are somewhat anomalous.

From fig. 1, it can be seen that with regard to cell dimensions the most consistent mean differences between the perithallial cells of the two species occur in cells three, four and five. A scatter diagram (Fig. 3) of means for these cells for each plant measured is given here only for the spring and summer since in these cases this is the period during which reproductive structures are most likely to be lacking. The same data for the entire year gives similar results, though there is more scatter. Using either diameter or length, there is a strong overlap of the two populations, but as one would expect from the general appearance of the two tissues, the overlap is less marked in the ratio. As indicated in the coefficient of variation curves and the scatter diagram, $P h$. laevigatum in general is much less variable in its perithallial cell dimensions than Ph. rugulosum. In the absence of 


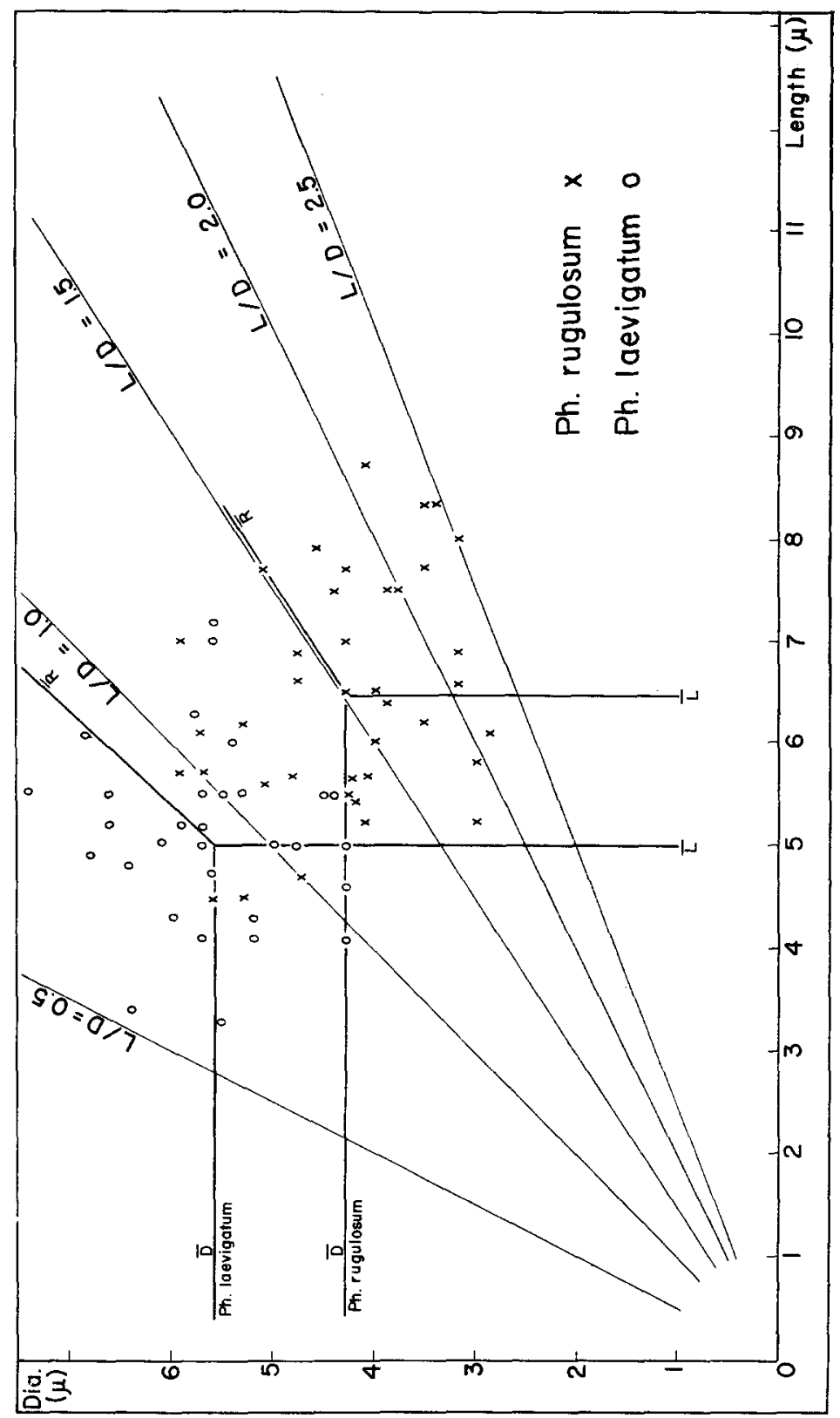

Fig. 3.

definitive surface markings, a scatter diagram of length and diameter derived from a hand section of a surface chip can sometimes provide accurate information as to which species is involved. This combined 
with the presence or absence of the 'staining body' discussed below and a consideration of available surface markings can lead to a fairly definite determination. Using the three-cell mean data, a significant difference in dimensions could not be obtained between those plants taken in shallow water and those in deeper water, nor could a significant difference be found between $P h$. laevigatum taken north of Cape Cod and that taken from south of the Cape.
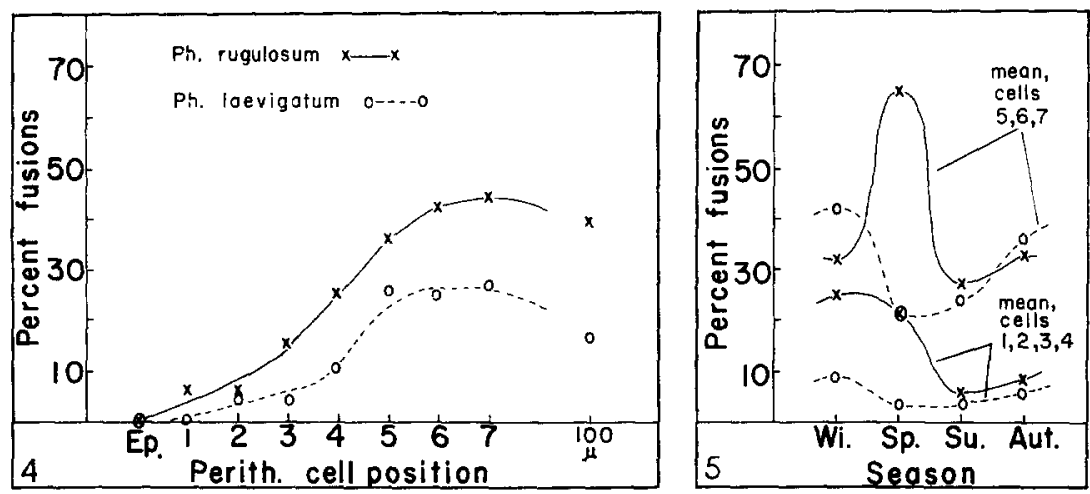

Figs. 4, 5.

Lateral fusions of perithallial cells occur in members of $P h y-$ matolithon. Data for Ph. rugulosum and Ph. laevigatum are presented in figs. 4, 5. There is a marked difference between the two species in the abundance of fusions, though both show the same consistent increase in fusion percentage with cell burial. However, both show a drop-off in percentage to the lower perithallium. This could result from a reformation of walls with burial below the upper perithallium, or possibly it reflects a difficulty in observation, since at $100 \mu$ depth in both plants the cell lumens are large and the walls separating adjacent cells thin.

In fig. 5, the relationship between season and abundance of cell fusions for the upper perithallium is given. A rising of cell fusion abundance in the uppermost perithallium (cells 1-4) in the winter in $P h$. laevigatum, and the spring in $P h$. rugulosum, probably as a result of a reduced rate of cell production, is seen in both species, though it is most marked in Ph. rugulosum where the fusions are more abundant at all seasons.

The white spots and ridges usually found in Phymatolithon laevigatum and Ph. rugulosum and mentioned above are shown in section in figs. 29,32 . These are apparently rapidly growing areas in which the upper dividing cells are relatively large, vacuolate and lacking in chromatophores. Oftentimes such growth spots are 
initiated at about the level of cell two or three in the perithallium, and then the overlying perithallium and cover cells are cut off upwards. Apparently this rapid growth does not persist and after about a halfdozen cells are formed, the tissue matures into normal perithallium.

Among the crustose corallines, hairs are known to occur in the genera Fosliella and Dermatolithon. Such cells have been called either trichocytes or heterocysts (KYLIN, 1956). However, the large cells of Porolithon and related genera are also generally referred to as heterocysts (HAMEL \& LEMOINE, 1953; MASON, 1953), though to the writer's knowledge these have never been shown to bear hairs or to be equivalent in any way to hair-bearing structures. In addition, SUNESON (1943) has described large cells in Melobesia limitata, a hairbearing species, which he suggests as possible vegetative reproductive structures. Thus, until the whole situation is properly worked out, the writer prefers the word trichocyte for a hair cell.

Trichocytes have not been previously found in the Lithothamnieae. In this study, they have been found, though quite sparingly, in Phymatolithon rugulosum (Figs. 51-54) but not as yet in Ph. laevigatum.

\section{Perithallial cytology}

This section is not intended in any sense as an exhaustive treatment of the cytology of these two species. It is based on light microscopy and is included only to point up a few interesting features of potential comparative value.

The general presence of pit connections between cells of a filament in Florideae is well known; KYLIN (1956) summarizes the literature. According to older interpretations, the pits ranged from open cytoplasmic connections to paired plates connected or not by plasmodesmata, or rings with an open passage or with closing membranes. Recent work with the electron microscope on a few red algae (MYers, Preston \& Ripley, 1959, and Bouck, 1962), indicate that the pit structure is probably variable and a number of the older interpretations correct.

Both Ph. laevigatum and Ph. rugulosum have the same type of pit structure. This consists of a very thin stainable plate which is oriented perpendicular to the filament axis and separates the two protoplasts. It is bounded in each cell by a spherical body heavily stained with phosphotungstic hematoxylin. The pit body in the upper cell is generally the larger of the two and ranges from about $0.7 \mu$ to $1.5 \mu$ in diameter. In some cases the central plate is very narrow, the pit then appearing as two spherical bodies connected by a thin line. A similar pit structure has been found in the members of Lithothamnium studied. This contrasts sharply with the pit structure of 
Clathromorphum compactum and C. circumscriptum. Here, the pit consists only of the plate, though this is somewhat more conspicuous.

The cell walls of all of the crustose corallines studied fail to stain with phosphotungstic hematoxylin, a single exception being the columnar thickening of the upper sporangial wall of branching species of Lithothamnium. However, Delafield's hematoxylin does stain the inner parts of the vegetative cell walls lightly, as well as the upper sporangial wall thickenings; the walls of the cover cells and the upper walls of cover cell precursors stain quite strongly. This same staining pattern is found in the rounded cover cells of Phymatolithon as well as the distinctive angular cover cells of the branching species of Lithothamnium. The cell walls of the entire epithallium (cover cell layer) of Clathromorphum become strongly stained in Delafield's hematoxylin.

In ground sections, the calcified walls of both species of Phymatolithon show faint parallel striae which are everywhere perpendicular to the surface of the cell wall. In a thinly-ground section, transmitted light polarized in a plane parallel to these lines is less absorbed than light polarized in a plant perpendicular to them. This would seem to agree with earlier conclusions (BAAS-BECKING \& GALLIHER, 1931) that the calcium carbonate in the cell walls of some corallines occurs as calcite crystals with their c-axis perpendicular to the cell wall surface. The calcified walls in members of Clathromorphum have a peculiar two-parted structure.

In the perithallial cells of Phymatolithon laevigatum, there frequently appears a spherical body of up to five microns in diameter which stains darkly with phosphotungstic hematoxylin. When welldeveloped, these become the most distinctive feature of the tissue in section (Fig. 33). In some plants or parts of plants they are very irregular in occurrence, sometimes being extremely abundant and being in nearly every cell. In other cases, they are very difficult to find, though a search will generally reveal a few. The nature of these bodies is unknown, though possibly they are a proteinaceous storage food. Oftentimes one cannot find nuclei in cells which bear these bodies, but sometimes very distinct nuclei are associated with them. They are distinct from both the chromatophores and the pit bodies, all three of these structures being usually distinguishable in a cell. A plot of abundance of these bodies with season of collection shows no apparent relationship. Such bodies have never been found in $P h$. rugulosum and they can therefore be very useful in the determination of fragments of sterile tissue. Unfortunately, they shrink badly in drying and are difficult to observe. Also, they stain only very lightly with Delafield's hematoxylin, so that their best use is attained only with fixed material that has been properly stained. 


\section{ASEXUAL REPRODUCTION}

Asexual reproduction in most corallines is accomplished by the production of sporangia in enclosed sori, i.e., conceptacles. The spore nuclei are apparently developed either by mitosis (generally bispores) or by meiosis (tetraspores) (SUNESON, 1950). In the Lithothamnieae, the sporangia develop thick, columnar, uncalcified upper walls or beaks and are continuously embedded in sterile tissue as they enlarge. By maturity, the calcification in the walls of the sterile tissue surrounding the middle and lower parts of the sporangia is dissolved, while the uncalcified, columnar upper walls of the sporangia are embedded in the calcified sterile tissue which forms the conceptacle roof. The spores produced in the sporangia are released either through the pore in the conceptacle roof produced by the breaking out of the upper part of the sporangial wall or by break-out of the entire conceptacle roof. According to the species, the conceptacles may either keep their roofs and become buried by overgrowth of vegetative tissue or the roofs may break out, the conceptacles subsequently becoming filled by the development of vegetative tissue from the old conceptacle base.

The asexual conceptacles in Phymatolithon in general follow the above pattern. However, the conceptacle primordium develops adventitiously deep in the perithallium, about $100 \mu$ from the surface in both $\mathrm{Ph}$. laevigatum and Ph. rugulosum, (Figs. 39, 45). The overlying tissue, which is calcified, is separated from the underlying perithallium by the primordium and is gradually raised up as the primordium develops (Figs. 40,46). This disc of tissue which has been seen in these species by many authors has been given a number of interpretations. SUNESON (1943) correctly interpreted the plugs in his treatment of Ph. polymorphum. However, since the degree to which the mature conceptacles were elevated or sunken in the tissue was somewhat variable and this was the basic criterion in FosLIE's definition, he discarded the genus Phymatolithon.

In the branching species of Lithothamnium that have been treated in this study (L. glaciale and two new species), as well as L. sonderi as diagrammed by SUNESON (1943), the conceptacle primordia develop directly from meristem cells and are overlain only by cover cells (Fig. 37). In the members of the genus Clathromorphum studied (C. compactum and C. circumscriptum), the conceptacle primordia also develop directly from the meristem cells. However, here the meristem itself is deeply sunken (Fig. 38), though it is overlain only by modified cover cells (epithallium).

A developmental series for the asexual conceptacles of Phymatolithon rugulosum is given in figs. 39-41, and for Ph. laevigatum in 
TABLE II

Dimensions of Conceptacles of $P$. rugulosum and P. laevigatum $(\mu)$.

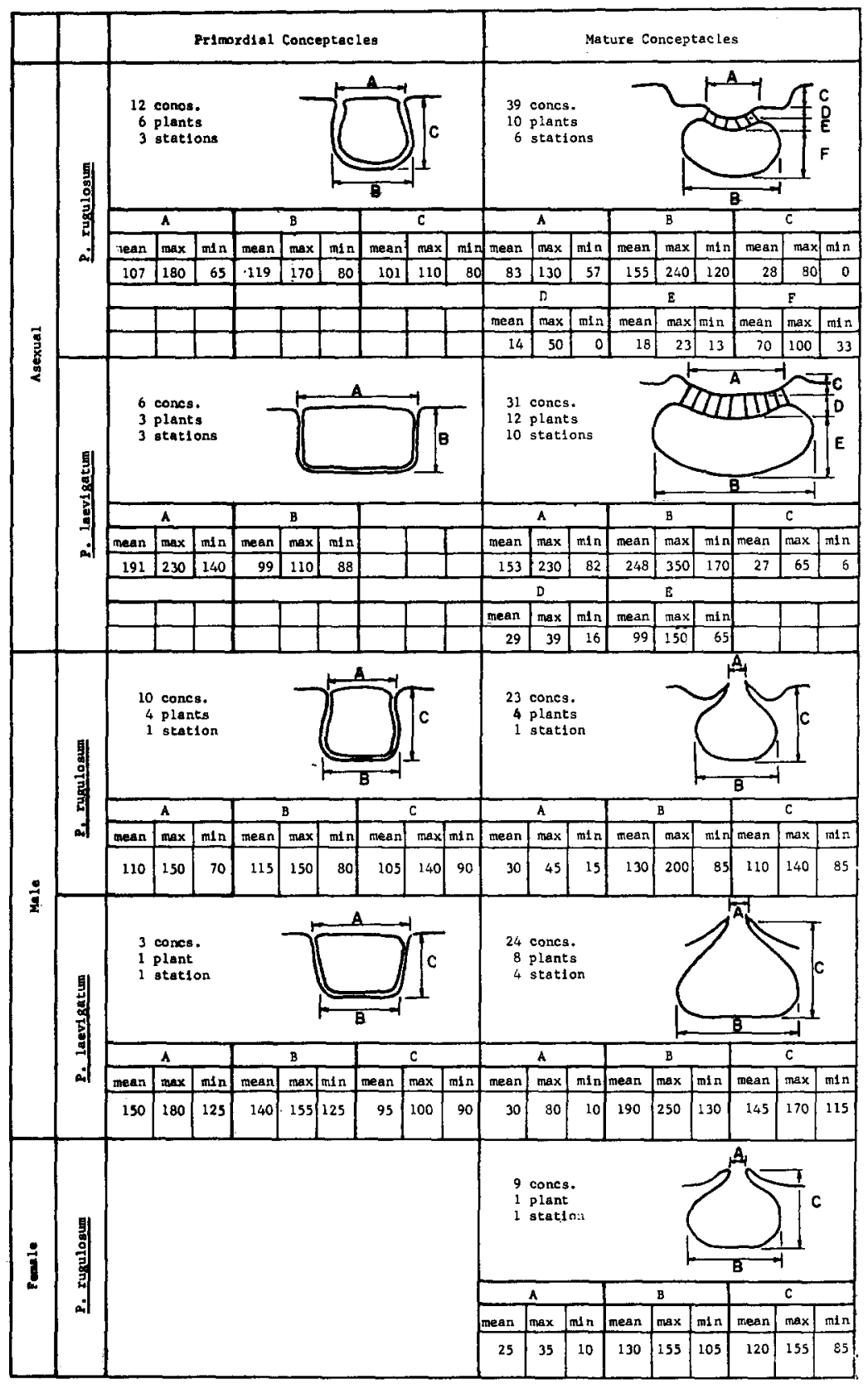




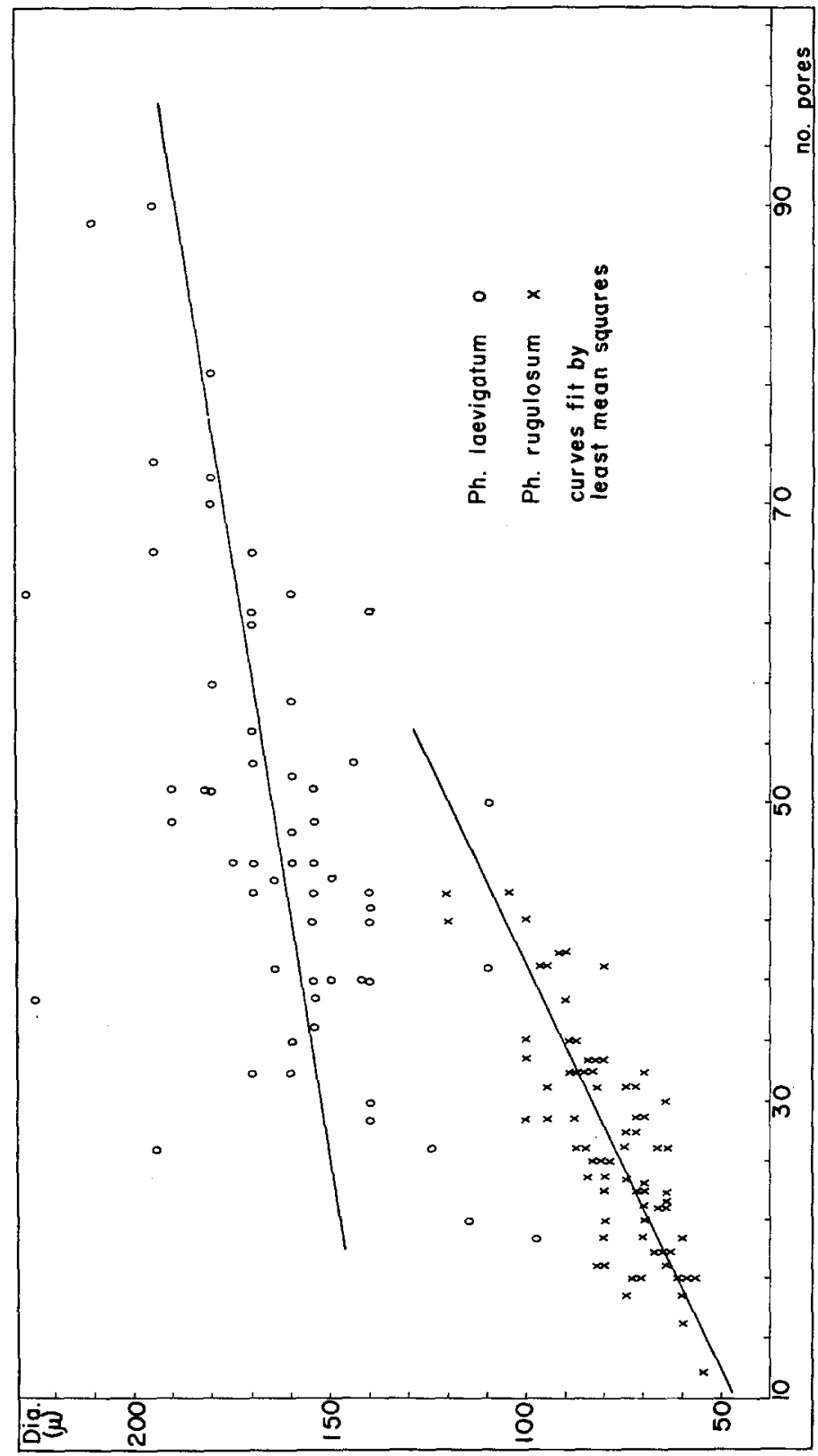

Fig. 6.

figs. 45-47. Data for the young and mature conceptacles of both species from sectional view appear in Table II. Surface views of young and mature conceptacles of Ph. laevigatum and Ph. rugulosum 


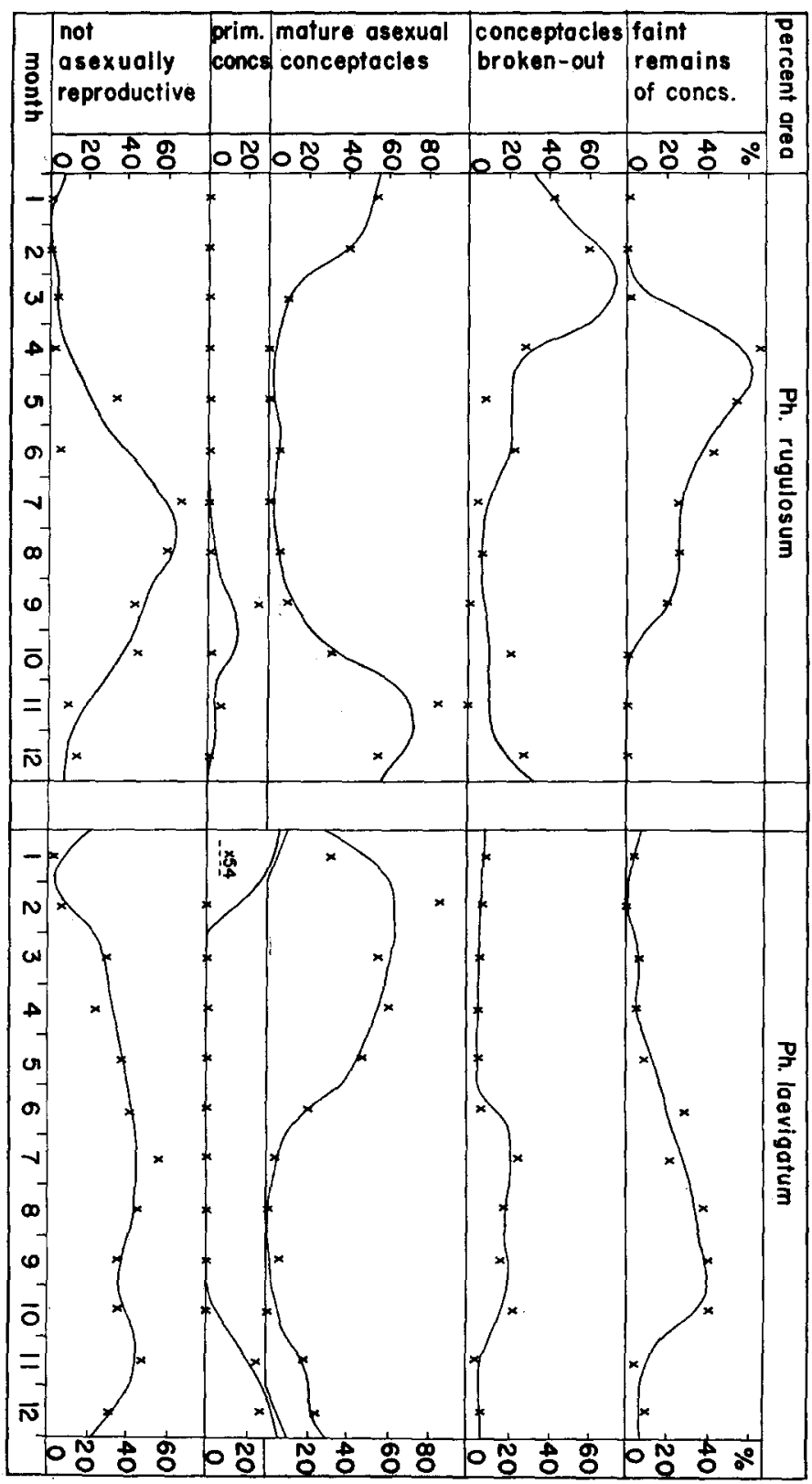

Fig. 7.

are given in figs. 19, 25. The conceptacle cap of the former species breaks out as a conspicuous disc (Figs. 25, 46), while in $P h$. rugulosum it appears to break up in pieces and is rarely very conspicuous. 
Usually an elevated rim is apparent surrounding the conceptacle roofs of Ph. laevigatum, while normally these are absent from conceptacles of Ph. rugulosum. A plot of pore plate diameter (i.e., roof diameter) as a function of the number of pores is given for both species in fig. 6. In most cases these data serve to distinguish reproductive plants of the two species.

In both species, bispores are very common, while tetraspores, either occurring singly or filling entire conceptacles, are quite rare. However, they have been found for both species in the Gulf of Maine (Figs. 42, 48). Release of the mature spores, in these species seems to be primarily through the pores, since empty, roofed conceptacles are common. Eventually, the roofs break out and the craters are refilled by new growth from below.

Estimates of percentage area of the different reproductive states on each specimen collected, combined to mean percentages for each collection and each month, and smoothed by taking bi-monthly moving averages of the collections are presented in fig. 7. During midsummer in $P h$. rugulosum, the plants are mostly lacking in asexual reproductive structures, though over 20 percent of the area tabulated still showed traces of the previous winter's conceptacles. A few plants bearing deep craters are still to be found; these are probably mostly plants from the undersides of wave-turned stones. In August, a few primordial conceptacles begin to appear followed closely by the appearance of the mature structures. The percentage of plants with primordial conceptacles is never very high, and the interval between their appearance as white spots and their breaking out is probably short. The maximum percentage of plants with mature conceptacles is reached in November and December and involves over 70 percent of the specimen area examined from these months. The peak of early degeneration is reached in February and March, and filling in of craters is well underway by May.

The asexual reproductive cycle of $P h$. laevigatum is basically similar to that of Ph. rugulosum; however, it follows the latter by about two months, the peak of mature conceptacles appearing in February and March rather than late in the autumn. Also, the breakout of the conceptacle caps is apparently quite slow, and in the late autumn plants bearing them form a major part of the population. The primary difference lies in the lack of a definite peak for empty craters and its low percentage. The interpretation suggested by the observation of many plants in these various stages and in section is that the roof of degenerate conceptacles in Ph. laevigatum is much more persistent than in the companion species. Here much development of new tissue in the conceptacle cavity occurs while the roof is 
still on, and when the roof is finally broken out, the conceptacle is mostly filled.

\section{SEXUAL REPRODUCTION}

Sexual conceptacles, athough commonplace in some crustose corallines, are quite scarce in many species, including those of the genus Phymatolithon. Apparently a mitotic division has generally been substituted for the reduction division in asexual sporangia (SunESON, 1950), the diploid plant then repeatedly reproducing itself by asexual reproduction. However, even in Ph. polymorphum, where tetrasporangia are the rule, sexual plants, especially female plants, tend to be rare.

This situation is characteristic of Ph. laevigatum and Ph. rugulosum in the Gulf of Maine. Sexual plants have been found in both species in this region, though their occurrence can be estimated as only about four percent of the population in Ph. laevigatum and less than one percent in Ph. rugulosum.

Sexual structures have not been previously described for $P h$. laevigatum. In spite of the relatively high percentage of sexual plants found in this study, only male plants are included. In general, they are similar to those described for Ph. polymorphum (SUNESON, 1943). The conceptacle primordia are here also initiated deep in the perithallium, a conceptacle cap then being cut-off as the conceptacle develops (Figs. 26, 49). The conceptacle roof is produced by overgrowth of the lateral perithallial tissue. At maturity the spermatia are borne in dendroid clusters completely clothing the conceptacle walls (Fig. 50). Data for these conceptacles are also given in Table II. Mature male conceptacles have been taken at all seasons of the year in the Gulf of Maine, but the great majority were collected in the autumn and winter. Intensive collecting during January and February south of Cape Cod might very well produce the desired female conceptacles.

Both male and female plants have been found in Ph. rugulosum, though here also the male plants were collected much in excess of the female. All the sexual plants found were taken in the autumn and winter. The male conceptacles, with their overgrowing roofs and dendroid clusters of spermatangia, are very much like those found in Ph. polymorphum and Ph. laevigatum. They are somewhat smaller, as would be expected from the small size of the asexual conceptacles. The size data for the male and female conceptacles are given in Table II. A male primordial conceptacle with its conceptacle cap is shown in fig. 43, and mature conceptacles are given in figs. 20 and 44. 
The female conceptacle in Ph. rugulosum is developed in the same manner as the male (Figs. 35, 36).

FOSLIE (1894) described the superficial aspects of the cystocarpic conceptacles of $P h$. polymorphum and Ph. investiens. For $P h$. polymorphum similar data have appeared in later works (TAYLOR, 1962; HAMEL \& LEMOINE, 1953). However, investigation of the structure of the female organs in section has been presented for the genus Phymatolithon only for Ph. polymorphum and only by $\mathrm{HEY}-$ DRICH (1900), RosENVINGE (1917), and Suneson (1943). HeYdrich described the procarp of $P h$. polymorphum as being two-celled, a supporting auxiliary cell and a carpogonium. After fertilization a fusion cell was not seen, the auxiliary cell supposedly becoming a carpospore. It was largely on the basis of these peculiar characteristics that he defined the genus Eleutherospora. RosENviNGE (1917) also studied the female structures, but unfortunately had only dried material to work with. He supported HEYDRICH's statements regarding the procarp and lack of a fusion cell, but stated that there was no evidence for the development of carpospores directly from auxiliary cells. He did find carpospores produced from the central part of the conceptacle in short rows, though did not have information as to how this occurred. SUNESON (1943) had only young female plants to work with, but disagreed with both HeYDRICH and Rosenvinge, and described a procarp consisting of a supporting auxiliary cell bearing a sterile cell and a carpogonial branch, the latter consisting of a hypogynous cell and the carpogonium.

The development of the procarp and the early stages following fertilization are shown for Ph. rugulosum in figs. 55-64. The pattern in $P h$. polymorphum, as near as can be discerned from the drawings in the literature, is probably very much like that found here. However, the situation is peculiar, and it is easy to see how some of the discordant statements mentioned above have arisen when based on little or poor material. The final stage available in this material is shown in fig. 63. Here, enlarged sterile cells have fused with the auxiliary cells along with the fused carpogonia-hypogynous cells. In addition, adjacent auxiliary cells have fused together in groups to form in a single conceptacle several irregular fusion cells. It seems possible, on the basis of HEYDRICH's (1900) and ROSENVINGE's (1917) studies, that the lobes which persist after the fusion of the enlarged sterile cells become the initials of short gonimoblast filaments. A hypothetical final stage illustrating this is shown in fig. 64. This may also be the explanation for the commonly seen but not yet explained situation in the well known Lithothamnium lenormandi. In any case, before this can be regarded as fully established, it will be necessary to obtain definitely mature cystocarpic conceptacles. 


\section{EcologY}

JoHNSON (1961) has summarized the accumulated general observations on the distribution of crustose coralline algae. However, there are almost no numerical data available concerning the ecology of these algae. Even in such a relatively well-known area as the New England littoral, very rudimentary information such as the species present, their general geographic and bathymetric distributions and their periods of reproduction is either non-existent or highly inaccurate. The methods employed in this study were designed to clear up some of these problems, and point out directions for more detailed field work and for experimental studies.

In the Gulf of Maine sublittoral, crustose corallines form the dominant incrustation on bottoms having a predominant constituent grain size larger than $1-2 \mathrm{~cm}$ and from low water to the lower limit of plant growth. The ecological data presented here were derived by measuring the area occupied by all the species of crustose coralline present on each specimen of rock or shell collected. For each collection and depth range, it was then possible to obtain the percentage abundance of these species as compared to the total surface occupied by coralline. Regional relative abundances are means of the values for the individual stations. Some attempt is made to analyze the factors responsible for the observations. However, in most cases a number of variables are probably involved in the determination of relative abundance, and the conclusions at this stage are necessarily only tentative.

Plants of Phymatolithon rugulosum are primarily sublittoral and are usually found above mean low water only in the lowest midlittoral pools or along wave channels. While Ph. laevigatum is found in greatest abundance in the sublittoral, it is common in lower intertidal pools throughout the region. In the Gulf of Maine, the only crustose corallines typically occurring intertidally are Clathromorphum circumscriptum, Lithothamnium lenormandi and $P h$. laevigatum, generally in that order of abundance. Where these occur at the same locality, there is a definite tendency for Ph. laevigatum to occur in the small pools and along fractures kept wet by rivulets, while $C$. circumscriptum occupies the larger pools and $L$. lenormandi the emergent rocks under the carpet of Ascophyllum and Chondrus. Thus, L. lenormandi is the only one of the intertidal corallines which is not continually immersed, and even this plant is normally kept wet by overlying algae.

In the sublittoral, $L$. lenormandi is on the whole not very important in the Gulf of Maine, accounting for only 0.26 percent of the tabulated area. Its ecology will be treated in detail at a later time. On the other 


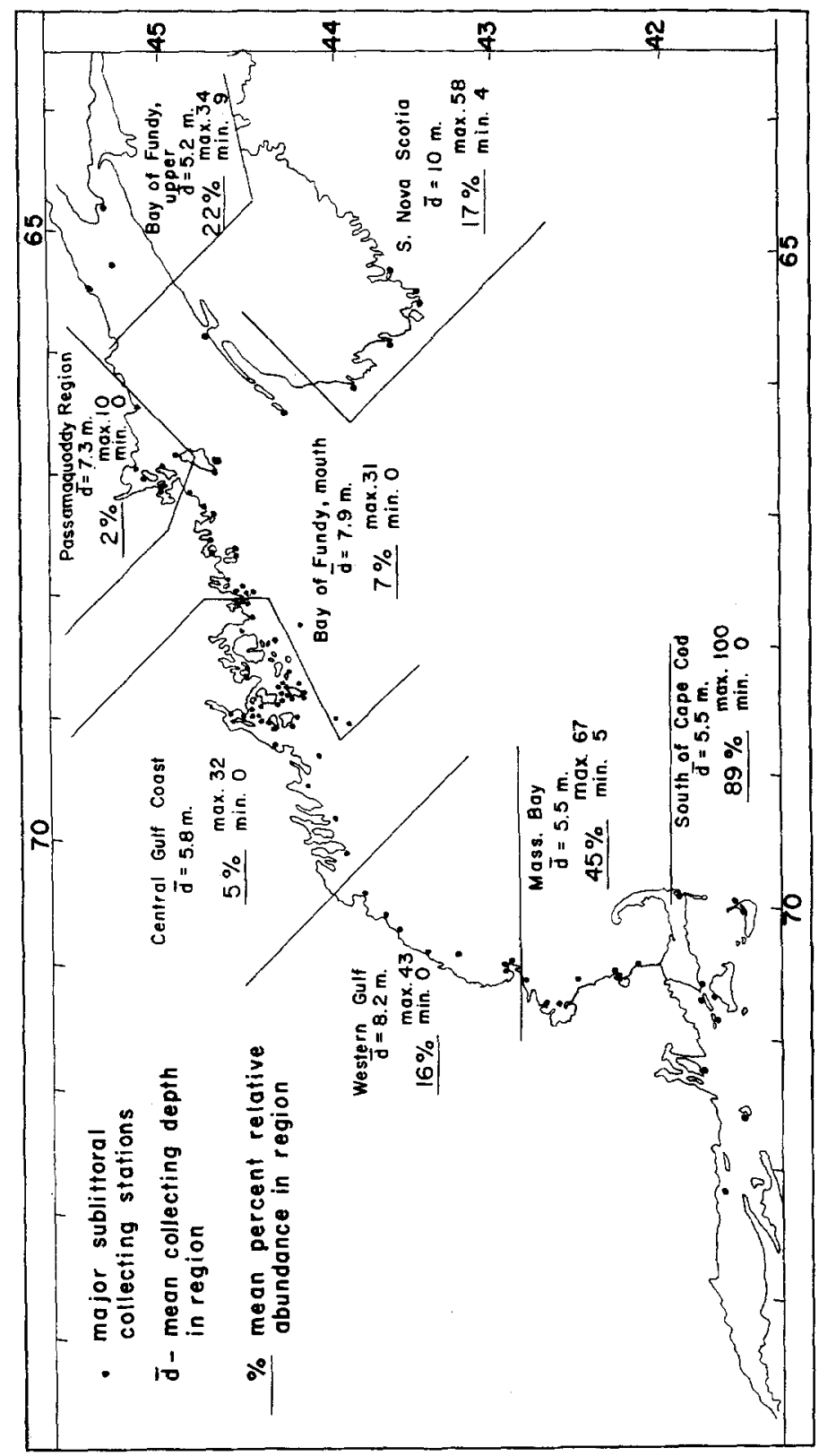

Fig. 8.

hand, Ph. laevigatum occurs throughout the region (Fig. 8), reaching its greatest relative abundance just south and west of Cape Cod, where it is the major rock and shell encrusting coralline. The only 
other species found south of Cape Cod in this study was Lithothamnium lenormandi. With the exception of a pure stand of the latter plant found in Nantucket Harbor, it was of minor importance, occurring at only two out of seven remaining stations and in relative amounts of less than two percent. The relative abundance of $P h$. laevigatum in the Gulf of Maine proper generally decreases northeastward (Fig. 8).

During the winter, the shallow sublittoral of the coastal Gulf of Maine has a mean minimum temperature of approximately $0.5-$ $1.5^{\circ} \mathrm{C}$., though it tends to be a little higher around the mouth of the Bay of Fundy and off S. W. Nova Scotia (BIGELOW, 1927; HACHEY \& BAILEY, 1952). The variation from one neighboring locality to another along the coast, depending on local conditions is likely to equal this variation in the region as a whole. On the other hand, there is a great difference in the summer mean maximum of the surface water from one part of the Gulf to another, ranging from about 20$21^{\circ} \mathrm{C}$. south of Cape Cod and $18-19^{\circ} \mathrm{C}$. in Cape Cod Bay to only $10-11^{\circ} \mathrm{C}$. in the mouth of the Bay of Fundy. At each collecting station in the present study a surface temperature was taken to within $0.5^{\circ} \mathrm{C}$. For the regions shown in fig. 8 , a mean of the readings taken from mid-July to mid-September has been obtained. This has

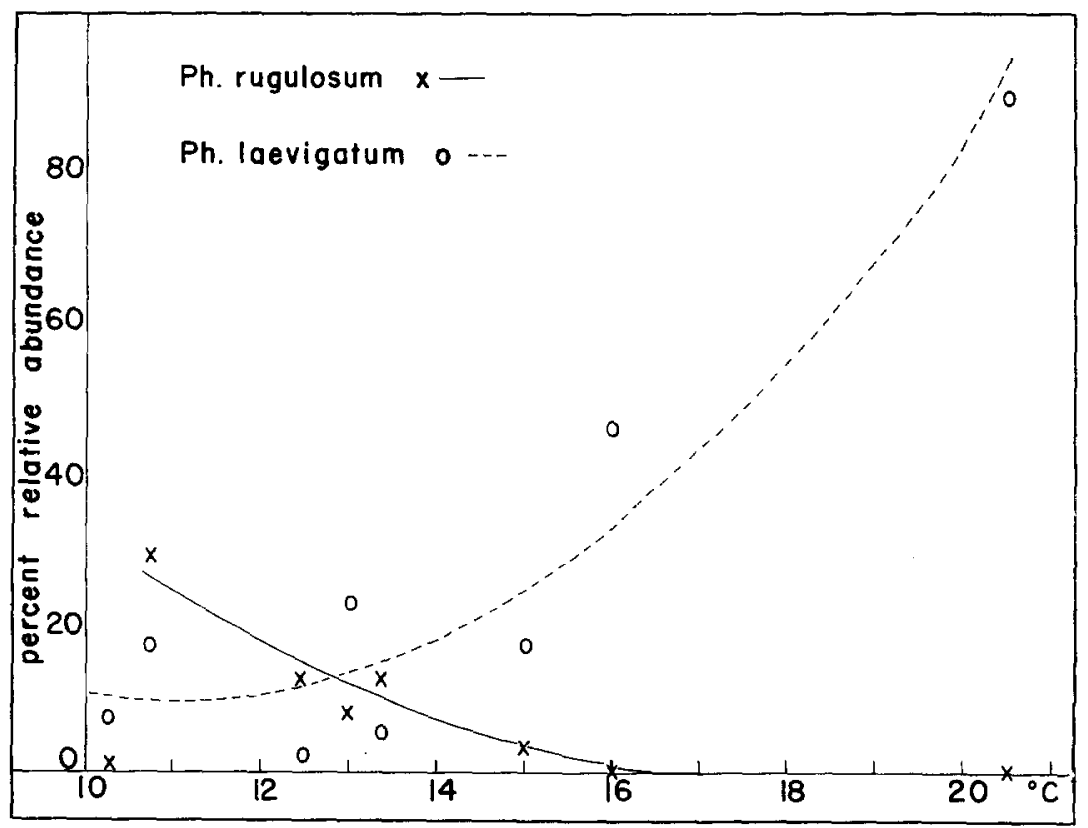

Fig. 9. 
been adjusted to the mean collecting depth (indicated in fig. 8) of the stations in each area by using typical vertical temperature distributions for the area in question from BIGELOW (1927), DAY (1959) and HACHEY \& BAILEY (1952). For the Passamaquoddy and upper Bay of Fundy regions, not enough stations were occupied during this time interval to obtain reasonable means, and the data of HACHEY \& BAILEY (1952), and TRITES (1962) were relied upon.

The regional mean relative abundance of $P h$. laevigatum as a function of regional mean maximum, depth adjusted temperature is given in fig. 9. For reference, a second order polynomial found by least mean squares is included. Thus, on a regional basis, there is a general decrease in the relative abundance of $P h$. laevigatum with a decrease in the summer temperature. The effect of low temperature here cannot be direct since the plants withstand much lower temperatures everywhere in the winter, while $P h$. laevigatum, being an inhabitant of small intertidal pools, must be especially resistant to low temperatures. However, it seems likely that $P h$. laevigatum is the only one of the important, sublittoral species present in the Gulf that is able to withstand temperatures over $18^{\circ}$ or $19^{\circ} \mathrm{C}$. None of the other major sublittoral crustose corallines in the region, Ph. rugulosum, C. circumscriptum, C. compactum, Lithothamnium glaciale, L. laeve and Pseudolithophyllum orbiculatum, were found south of Cape Cod, and all of them showed a general increase in relative abundance with drop in summer temperature corresponding with the decrease in abundance of Phymatolithon laevigatum (Fig. 10). Much of Cape Cod is sandy and generally unsuitable for a strong development of the rock encrusting corallines. At one time it may have been an important barrier to the passage north or south of these plants. However, the western shore of Cape Cod Bay is quite bouldery as is Buzzards Bay to the south of the Cape, and these bays have been connected for many years by the rock-lined Cape Cod Canal. Except for the large summer temperature gradient, there is no apparent reason why Clathromorphum circumscriptum and Lithothamnium glaciale, which occur abundantly along the eastern side of Cape Cod Bay, could not extend southward.

In the colder waters of the eastern part of the Gulf, Ph. rugulosum is one of the species that replaces Ph. laevigatum (Figs. 10,11). Its mean relative abundance as a function of summer temperature is also given in fig. 9. The lowest temperature and the south of the Cape high temperature were omitted in obtaining the reference polynomial. The species of Clathromorphum and Pseudolithophyllum showed a continuing increase in relative abundance with temperature decrease, while Lithothamnium glaciale showed a peak in the middle region of the temperature scale shown here and Phymatolithon 


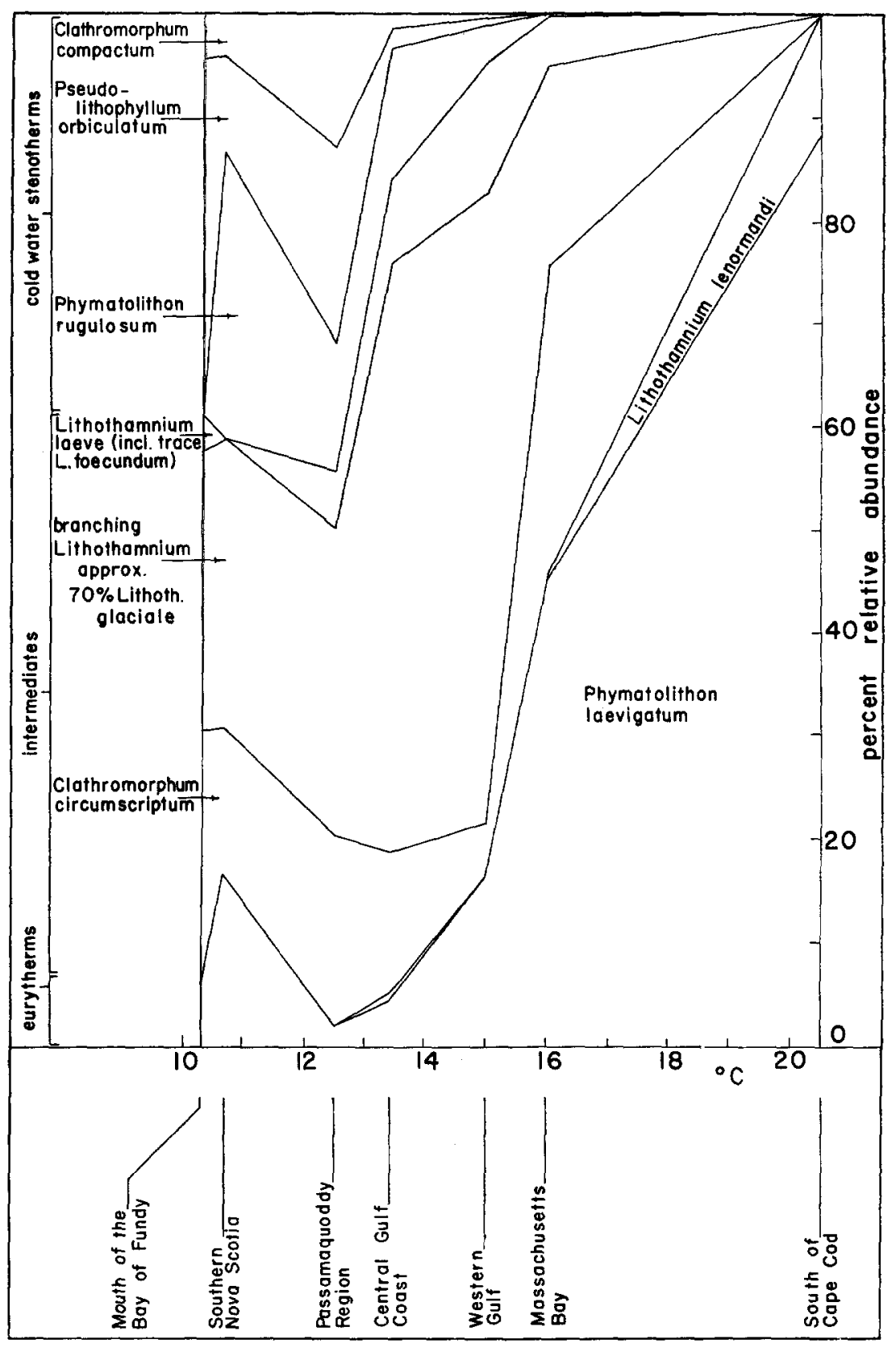

Fig. 10. 


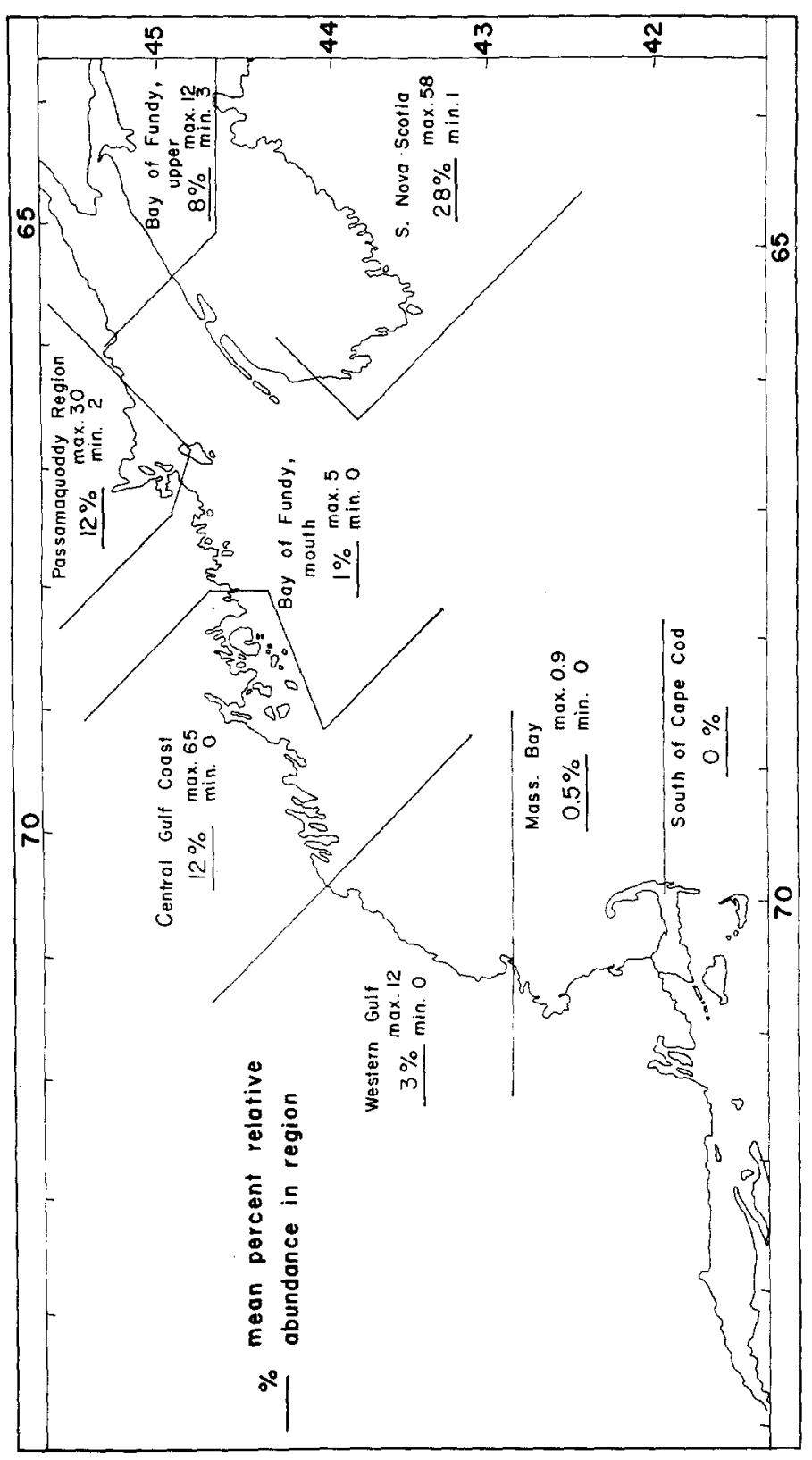

Fig. 11. 
rugulosum showed a sharp drop off in the coldest water around the mouth of the Bay of Fundy. The data from the mouth of the Bay of Fundy region was taken from fifteen stations, and the relative abundance of $P h$. rugulosum was consistently low, showing a maximum of only 4.9 percent. Ph. rugulosum is apparently replaced by Pseudolithophyllum orbiculatum which reaches a peak of abundance in this region. On the other hand, the stations of the southern Nova Scotia region $\left(10.7^{\circ} \mathrm{C}\right.$.), although fewer in number (five) showed high percentages, four out of five being over 20 percent.

In fig. 12, the relationship between relative abundance and depth is given for both species of Phymatolithon. The data are given on a regional basis, including only those regions with sufficient depth data to give reasonable results. The relative abundance values are means of station percentages, at 3 meter intervals. The number of stations from which the data for each interval were taken are included.

In the central Gulf coast and Passamaquoddy regions, where $P h$. rugulosum is abundant, it reaches a peak in the uppermost 6 meters of the sublittoral, and shows a marked decrease in relative percentage with depth. Its high relative abundance does not extend to low water mark, the one to two meter band just below low water being primarily occupied by Clathromorphum circumscriptum. In the Bay of Fundy and western Gulf regions where the plant is of relatively minor importance, the peak of abundance occurs at greater depth.

Except in the Bay of Fundy region where strong tidal mixing prevents the development of a marked summer stratification, there is a general decrease of temperature with depth. To some extent, this apparently affects the depth distribution of some species. In Massachusetts Bay, the only $P h$. rugulosum found was taken below 9 meters, that is, below the $16^{\circ}$ summer isotherm. In the western Gulf, the peak of abundance is from 3-9 meters, also below the $16^{\circ}$ summer isotherm. Similar situations occur with the cold water species Clathromorphum compactum and Pseudolithophyllum orbiculat um However, since there is no marked increase in the abundance of Ph. rugulosum at depth in either of these areas, the depth distribution is likely mostly controlled by other factors, probably primarily light.

In the island area south of Deer Isle in the central Gulf coast region, gently sloping, relatively smooth granite shores are not uncommon. Beginning at low water and extending to $1-2$ meters depth, these are primarily occupied by Clathromorphum circumscriptum. Below 2 meters Phymatolithon rugulosum becomes increasingly abundant. At 3-4 meters, the surface is occupied mostly by Ph. rugulosum and branching members of Lithothamnium. This species stratification could be controlled either by light or temperature. However, erratic cobbles and boulders occur on these smooth 


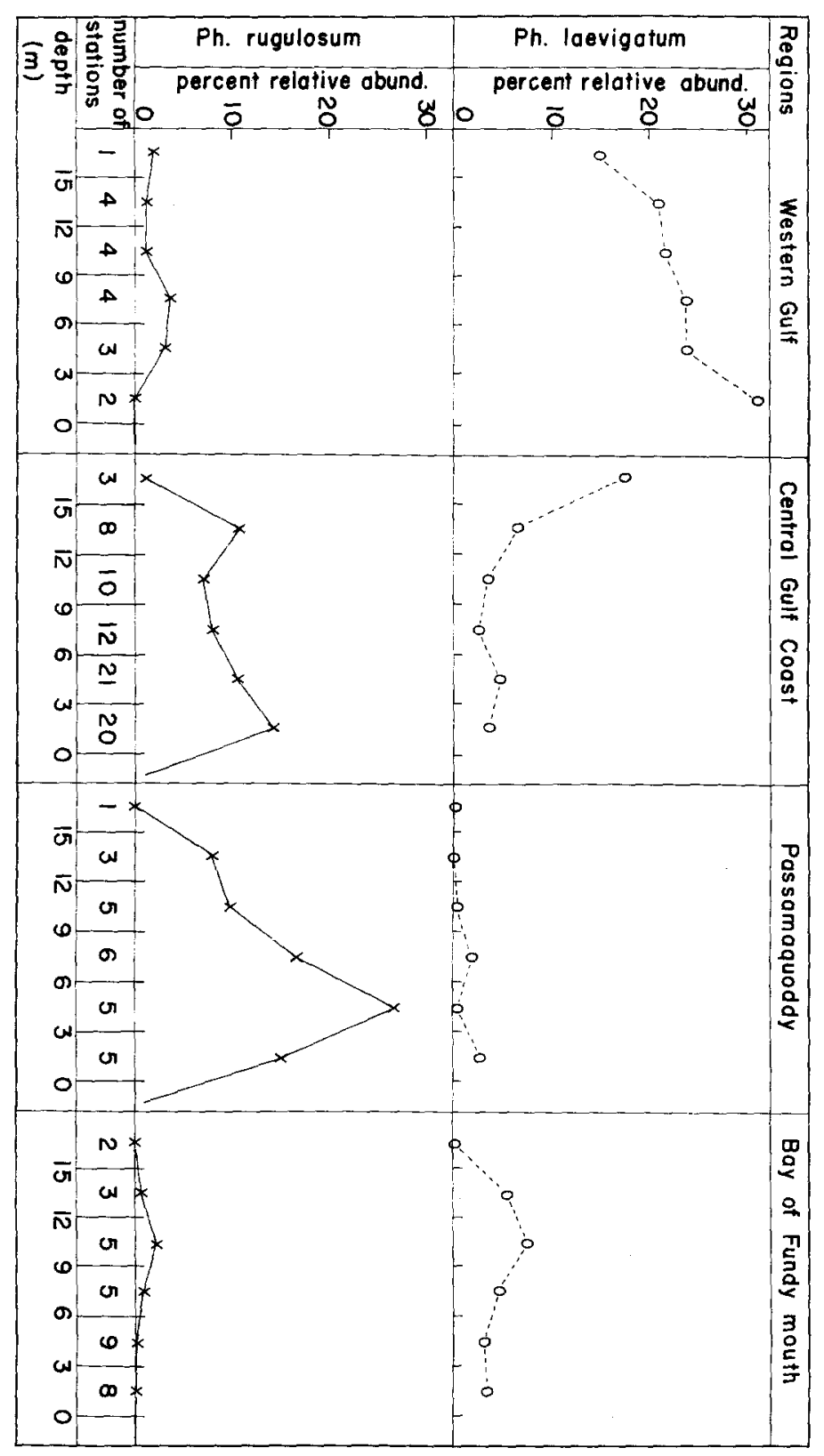

Fig. 12 . 
ledges, and where these lie in 1-2 meters of water, their upper surfaces are covered primarily with $C$. circumscriptum while their sides and bottoms (where open) are coated mostly with $P$ h. rugulosum and branching members of Lithothamnium. This is further indication that the primary factor controlling depth distribution in these cases is light.

The depth curves for $P h$. laevigatum are more variable from one region to the next, than any other species. Probably with regard to light as well as temperature, this species is highly tolerant in its requirements.

One of the factors affecting the depth distribution of these species is substrate. In highly protected localities deposition of fine materials prevails throughout the intertidal and below, and crustose corallines, other than the species epiphytic on eel grass, do not generally occur. With increasing exposure, depending upon slope of the bottom and type of consolidated materials, the rocky intertidal substrate extends below low water and at some point usually grades into sand, gravel or mud. In the central regions of the large bays, Penobscot, Blue Hill, Frenchman and Passamaquoddy, the sublittoral is frequently rocky down to a depth of 3-6 meters. This bottom is commonly dominantly occupied by crustose corallines in association with sea cucumbers, sea urchins, brittle stars, limpets and relatively small amounts of kelp and Chondrus, with Ph. rugulosum being an important constituent. In some areas where the bottom is relatively flat, small pebbles are abundant, the ocean swell is reduced and sufficient fetch is available for the development of a good chop, a bottom develops which consists primarily of pebbles thickly coated with corallines. Clathromorphum circumscriptum and branching species of Lithothamnium, the latter oftentimes breaking free of the substrate and continuing growth in the free state, are the most important constituents of this type of bottom. Phymatolithon rugulosum tends to be relatively unimportant on these bottoms and shows a strong tendency to be absent on the smaller fraction bearing coralline (Fig. 13).

In fig. 14, the depth data for Ph. rugulosum in the central Gulf region are separated arbitrarily into bay stations and outer stations. In the bay stations the plant reaches a peak of relative abundance in quite shallow water generally dropping-off with depth. However, offshore the peak is broad and flat extending to greater depths. This extension of $P h$. rugulosum to greater depths offshore is probably primarily due to clearer water.

Mollusk shells, in addition to rock, commonly bear crustose corallines. In this region, Modiolus is abundant below 3-6 meters and the shells, dead or alive, are usually encrusted with corallines. 


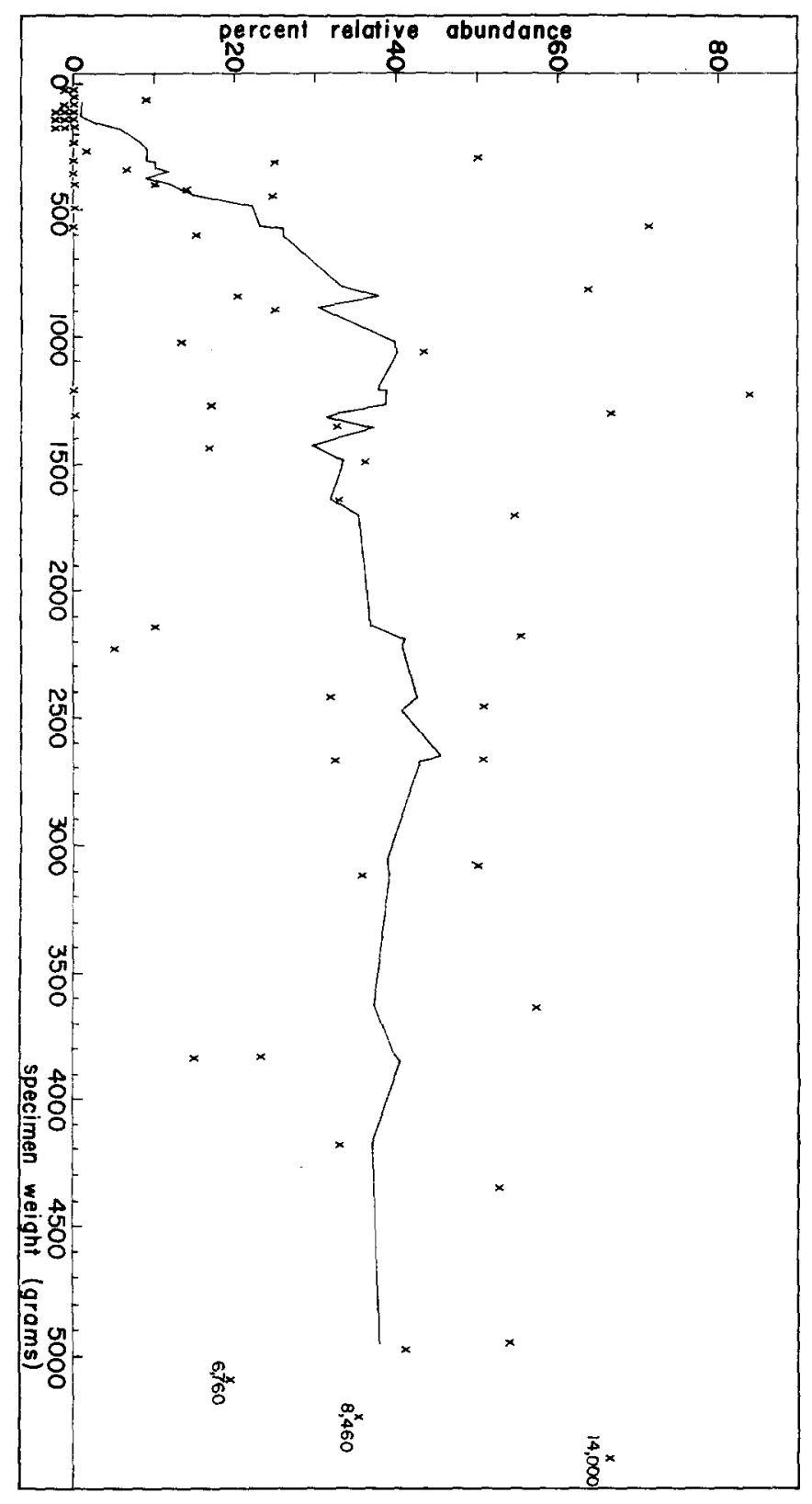

Fig. 13. 


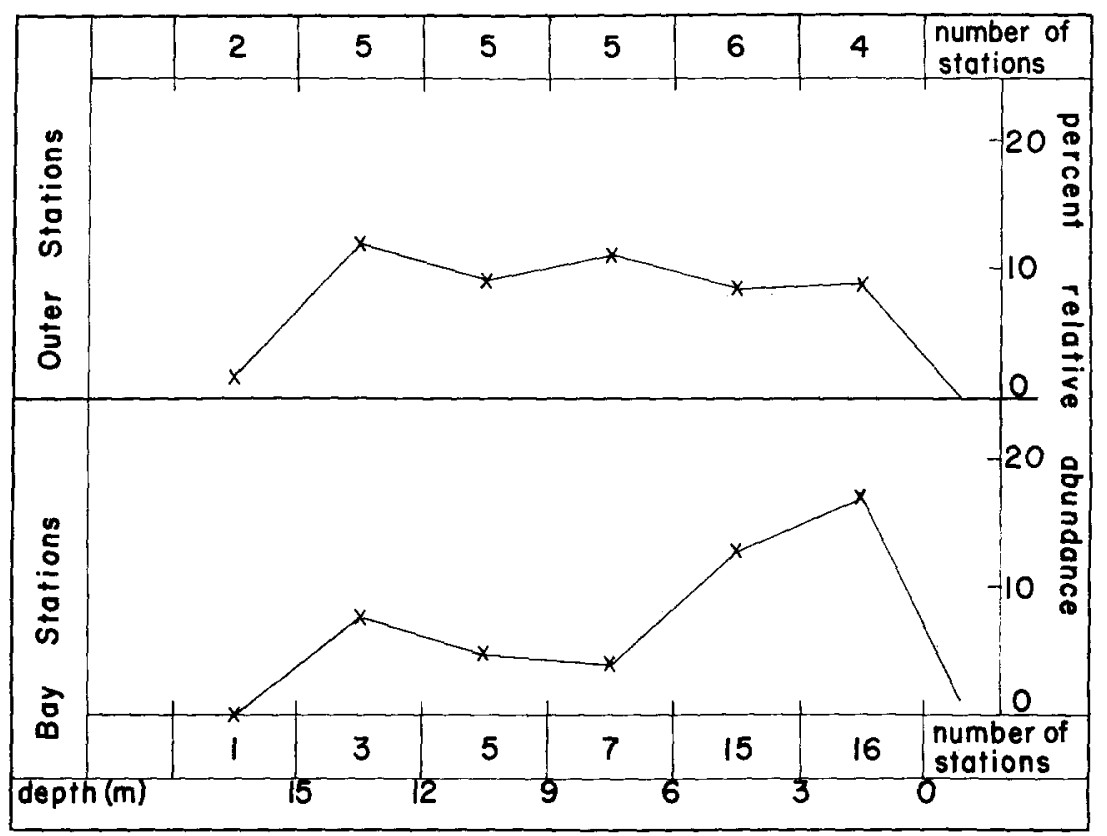

Fig. 14.

For each of the collections having Modiolus, a percentage abundance of each species on live Modiolus was calculated. A mean for all of the collections for each species was then taken. These values are dependent upon the relative amounts of Modiolus and rock material in a collection, but overall they provide a method of comparison between the species. Phymatolithon rugulosum and Clathromorphum circumscriptum show Modiolus means of $10.5 \%$ and $15.2 \%$ respectively, while most of the other species showed greater amounts. A low percentage in these cases is to be expected, however, since they are most abundant in water shallower than that usually occupied by Modiolus. However, Ph. laevigatum showed a Modiolus mean of only $0.13 \%$. The collections involved are so large that it is quite likely that $\mathrm{Ph}$. laevigatum for some unknown reason does not develop on live Modiolus shell. This is especially peculiar, since it does occur in abundance on live Mytilus shells.

\section{SUMMARY}

New information on anatomy, cytology and the development of reproductive structures is presented to show that Phymatolithon is a genus distinct from both Clathromorphum and the branching 
members of Lithothamnium. Also, a new species of Phymatolithon, $P h$. rugulosum, is described. The reproductive cycles and geographic and bathymetric distributions of $P h$. laevigatum and $P h$. rugulosum in the Gulf of Maine are presented and discussed. There is strong indication that the geographic distribution of crustose corallines in the region is controlled primarily by maximum summer temperatures. The depth distributions are apparently controlled primarily by decrease of light with depth, though temperatures and substrate are also factors.

\section{LITERATURE CITED}

BaAs-Becking, L. G. M. \& Galliher, E. W. - 1931 - Wall structure and mineralization in coralline algae. $\mathcal{F}$. phys. Chem., 35: 467-479.

Batters, E. A. L. - 1902 - A catalogue of the British marine algae. F. Bot. (Brit. \& For.), 40 (Supplement): 107 pp.

Bigelow, H. B. - 1927 - Physical oceanography of the Gulf of Maine. Bull. U. S. Bur. Fish. 40 (2): 511-1027. 1924.

Børgesen, F. - 1902 - The Marine Algae of the Faeröes. p. 339-352, figs. 51-110. Bot. of the Faeröes, part 2. Copenhagen.

BoucK, G. B. - 1962 - Chromatophore development, pits and other fine structure in the red alga, Lomentaria baileyana (HARV.) FARLOW. 7. Cell. Biol., 12 (3): 553-569, 21 figs.

DAY, C. G. - 1959 - Oceanographic observations, 1957, east coast of the United States. U. S. Dept. of Int., Fish and Wild. Serv., Special Scientific Reports, Fisheries no. 282: 1-123, 17 figs.

De TonI, G. B. - 1905 - Sylloge algarum omnium hucusque cognitarum. 4(4): $1523-1973$.

FARLOW, W. G. - 1881 - The marine algae of New England. Rep. U. S. Comm. Fish and Fisheries for 1879, Appendix A-1: 1-210. (1882).

FosLIE, M. H. - 1894 - The Norwegian forms of Lithothamnion. $K$. Norske Vidensk Selsk. Skr., 1894: 29-208, 23 pls.

1898a - Systematical survey of the Lithothamnia. Ibid., 1898 (2): 1-7.

- $1898 \mathrm{~b}$ - List of species of the Lithothamnia. Ibid., 1898 (3): 1-11.

1900 - Revised systematical survey of the Melobesieae. Ibid., 1900 (5): $1-22$.

1901 - New Melobesieae. Ibid., 1900 (6): 1-24.

—_ 1905 - Remarks on northern Lithothamnia. Ibid., 1905 (3): 1-138.

1908 - Algolgiske Notiser V. Ibid., 1908 (7): 1-20.

1929 - Contributions to a Monograph of the Lithothamnia. Edited by H. Printz. 60 pp., 75 pls. Trondheim.

HACHEY, H. B. \& BAILEY, W. B. - 1952 - The general hydrography of the waters of the Bay of Fundy. Revision. Fisheries Res. Bd. of Canada. Manuscript reports of the biological sta. No. 455.

Hamel, G. \& Lemoine, M. - 1953 - Corallinacées de France et d'Afrique du Nord. Arch. Mus. Nat. Hist. Nat., vii, 1: 15-136, 83 figs., 23 pls.

HeYdrich, F. - 1897a - Corallinaceae, inbesondere Melobesieae. Ber. dtsch. bot. Ges., 15: 34-70, 3 figs., pl. 3. 1897b - Melobesieae. Ibid., 15: 403-420, pl. 18. 


\section{CAPTIONS}

for

\section{PLATES}

\section{Symbols Used}

Pr. Phymatolithon rugulosum

PI. Ph. laevigatum

Ep. Epithallium

c.c. Cover cells

C.ci. Clathromorphum circumscriptum Pri. Conceptacle primordium

Lg. Lithothamnium glaciale

Hp. Hypothallium

Per. Perithallium

Cp. Conceptacle cap

Ysp. Young sporangium

Splg. Sporangial plug

\section{PLATE I}

Fig. 15. Ph. rugulosum, large cobble, coll. $3-7.5$ m., Schoodic Pt., eastern Maine.

Fig. 16. Ph. rugulosum, large cobble, coll. 0-4.5 m., Kimball Is., Isle au Haut Bay, Maine.

Fig. 17. Ph. rugulosum, enlargement of area shown in Fig. 16.

Fig. $18 \mathrm{Ph}$. rugulosum, mature asexual conceptacles, $\times 1.8$.

Fig. 19. Ph. rugulosum, primordial and mature asexual conceptacles, $\times 50$. Note conceptacle cap orlens of degenerating tissue over conceptacle primordium.

Fig. 20. Ph. rugulosum, sexual conceptacles, $\times 50$. Note irregular breaking out of conceptacle cap.

Fig. 21. Ph. laevigatum, large cobble, coll. 0-4.5 m., Center Hill Pt., Cape Cod Bay

Fig. 22. Ph. laevigatum, large cobble, coll. 1.5-3 m., Long Is., Penobscot Bay.

Fig. 23. Ph. laevigatum, small cobble, coll $1.5-3 \mathrm{~m}$., Center Hill Pt., Cape Cod Bay.

Fig. 24. Ph. laevigatum, asexual conceptacles with and without caps overlying developing primordia, $\times 1.8$.

Fig. 25. Ph. laevigatum, young and mature asexual conc., $\times 50$.

Fig. 26. Ph. laevigatum, young and mature male conc., $\times 50$. 


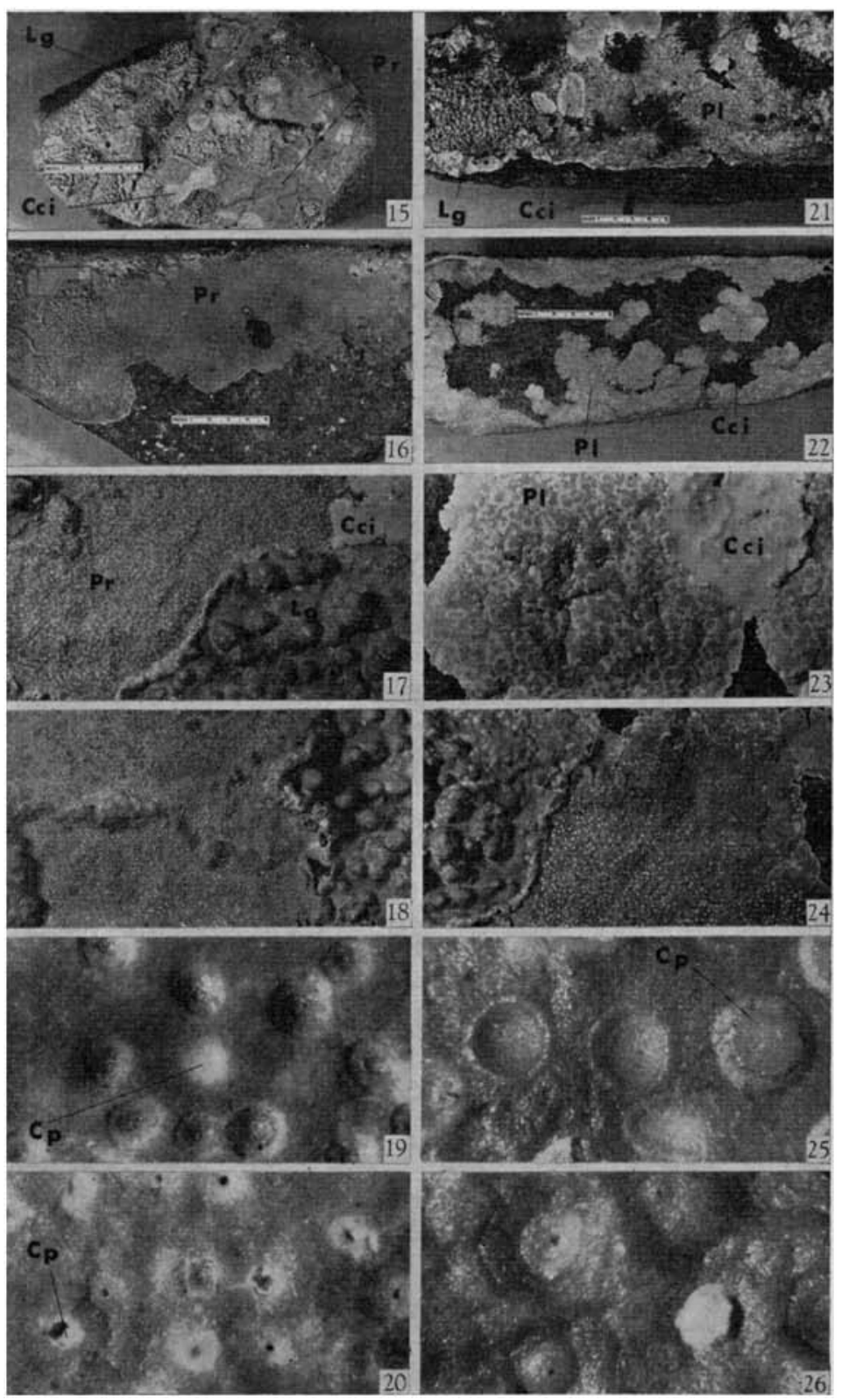




\section{PLATE II}

Fig. 27. Ph. rugulosum, growing margin, $\times 320$.

Fig. 28. Ph. rugulosum, hypothallium, $\times 320$

Fig. 29. Ph. rugulosum, "white ridge" in section, $\times 220$.

Fig. 30. Ph. laevigatum, growing margin, $\times 320$.

Fig. 31. Ph. laevigatum, hypothallium, $\times 320$.

Fig. 32. Ph. laevigatum, "white ridge" in section, $\times 220$.

Fig. 33. Ph. laevigatum, spherical staining bodies of unknown nature, $\times 320$.

Fig. 34. Ph. laevigatum, layers of cover cells, $\times 320$.

Fig. 35. Ph. rugulosum, young female conceptacle, $\times 220$.

Fig. 36. Ph. rugulosum, mature female conceptacle, $\times 220$.

Fig. 37. Lithothamnium glaciale, asexual conceptacle primordium, $\times 220$.

Fig. 38. Clathromorphum circumscriptum, asexual conceptacle primordium, $\times 220$. 


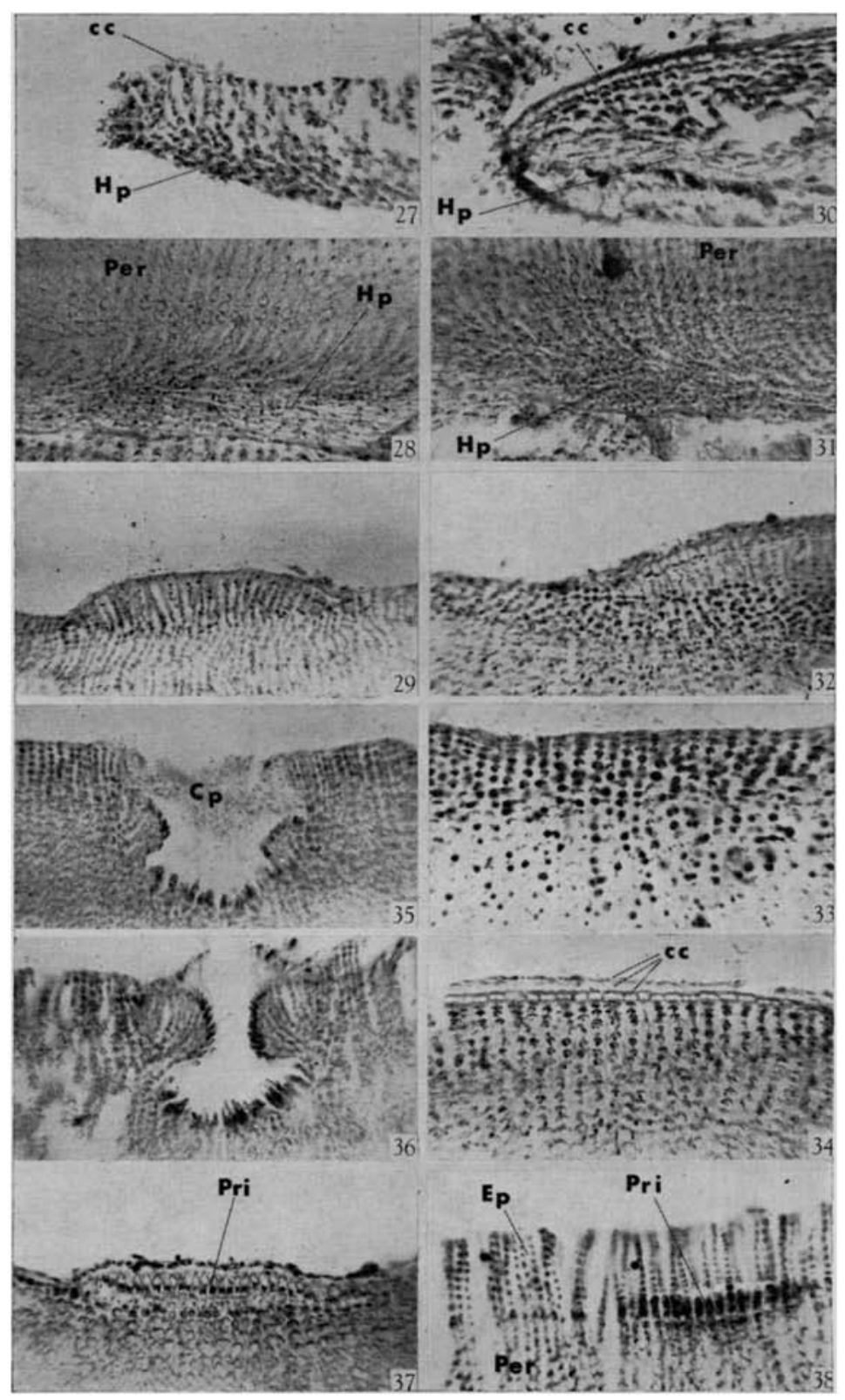




\section{PLATE III}

Fig. 39. Ph. rugulosum, asexual conceptacle primordium with conceptacle cap, $\times 220$.

Fig. 40. Ph. rugulosum, asexual conceptacle, intermediate stage of development, $\times 220$.

Fig. 41. Ph. rugulosum, mature asexual conceptacle with bispores, $\times 220$.

Fig. 42. Ph. rugulosum, tetrasporangium, $\times 220$.

Fig. 43. Ph. rugulosum, primordial male conceptacle, $\times 220$.

Fig. 44. Ph. rugulosum, mature male conceptacle, $\times 210$.

Fig. 45. Ph. laevigatum, asexual conceptacle primordium with conceptacle cap, $\times 220$.

Fig. 46. Ph. laevigatum, asexual conceptacle, intermediate stage of development, $\times 220$.

Fig. 47. Ph. laevigatum, mature asexual conceptacle with bispores, $\times 220$.

Fig. 48. Ph. laevigatum, tetrasporangia, $\times 220$.

Fig. 49. $P h$. laevigatum, young male conceptacle, $\times 220$.

Fig. 50. Ph. laevigatum, mature male conceptacle, $\times 220$. 


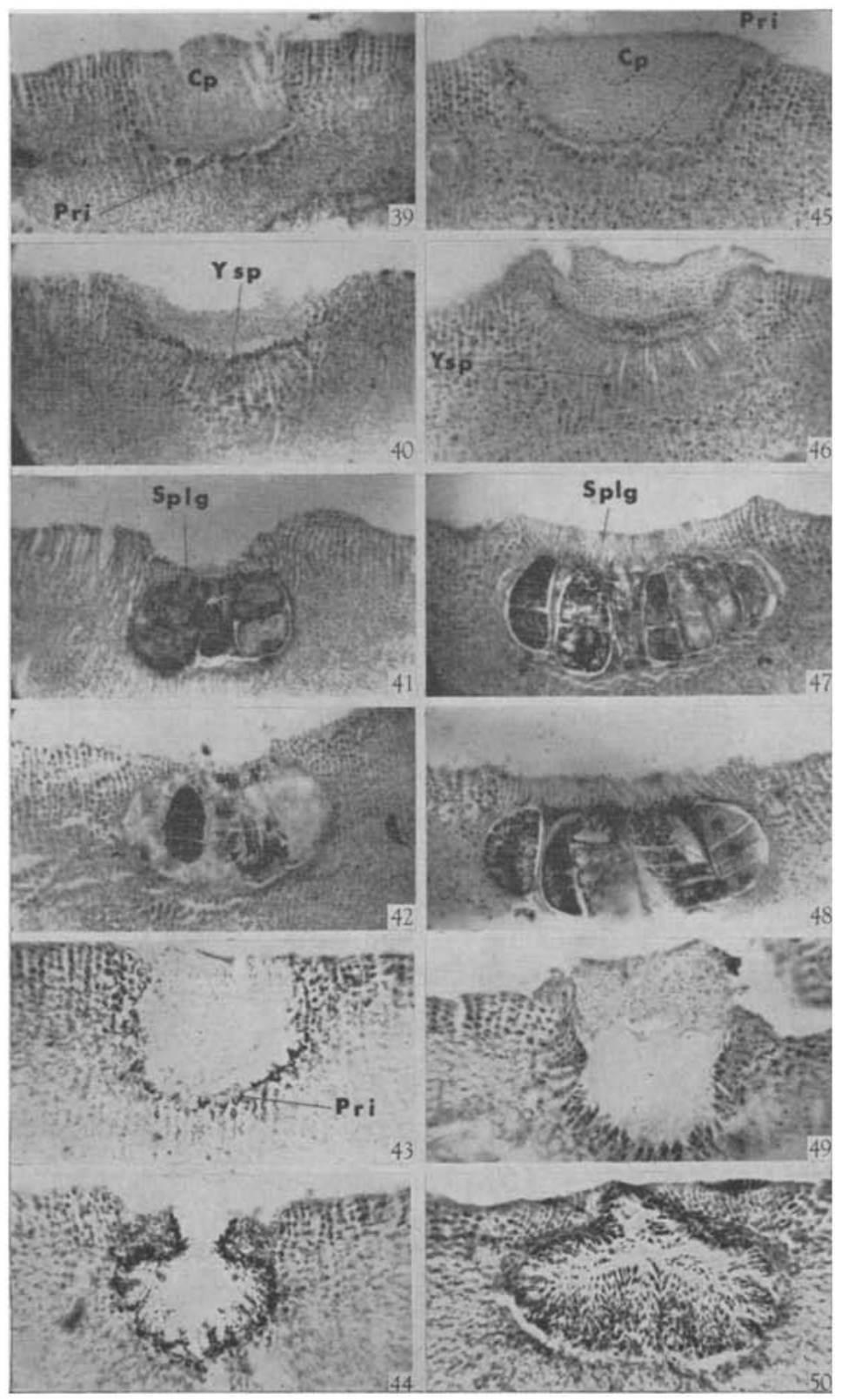


กั
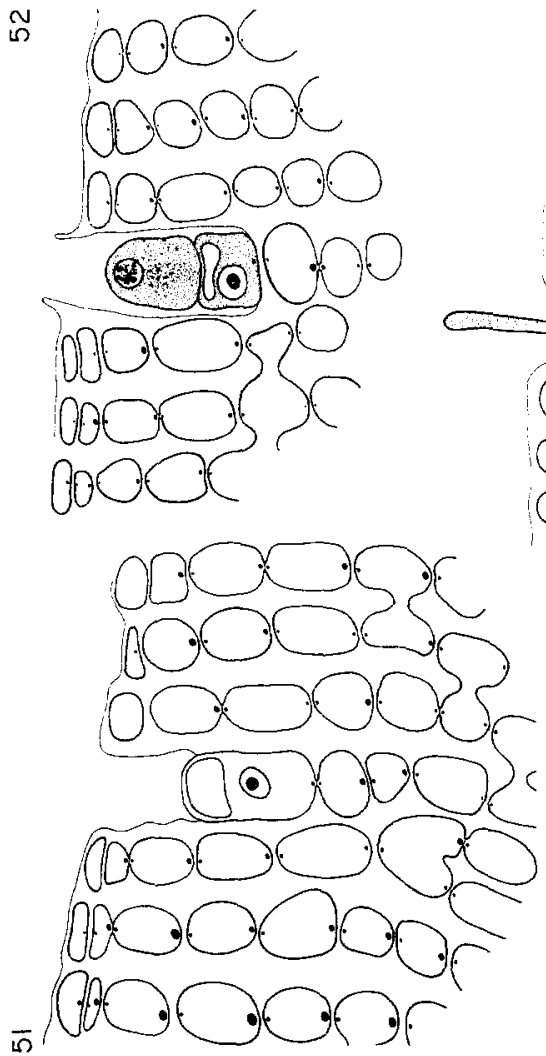
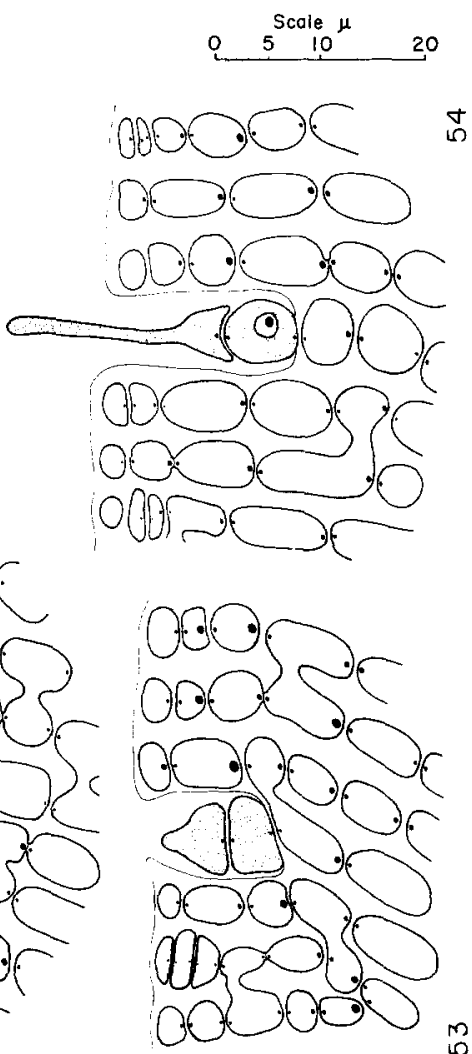

PLATE IV

Figs. 51-54. Development of trichocytes in Phymatolithon rugulosum.

\section{PLATE V}

Figs. 55-64. Development of carpogonia and early stages of cystocarp of $P h$. rugulosum. (55) procarp initial; (56) auxiliary cell, two sterile cells and carpogonial branch initial; (57) division of carpogonial branch intitial; (58) mature procarp; (59) procarp, probably shortly following fertilization, wall of basal part of carpogonium and hypogynous cell become densely stained; (60) carpogonium and hypogynous cell fuse; $(61,62)$ trichogyne withers; (63) auxiliary cells fuse to form fragmentary fusion cell, fused carpogonialhypogynous cells also fuse to auxiliary cells, larger sterile cells enlarge and fuse to auxiliary cells; (64) HYPOTHETICAL, protrusions formed by fusion of large sterile cells to fusion cell enlarge and divide to form short gonimoblasts. 

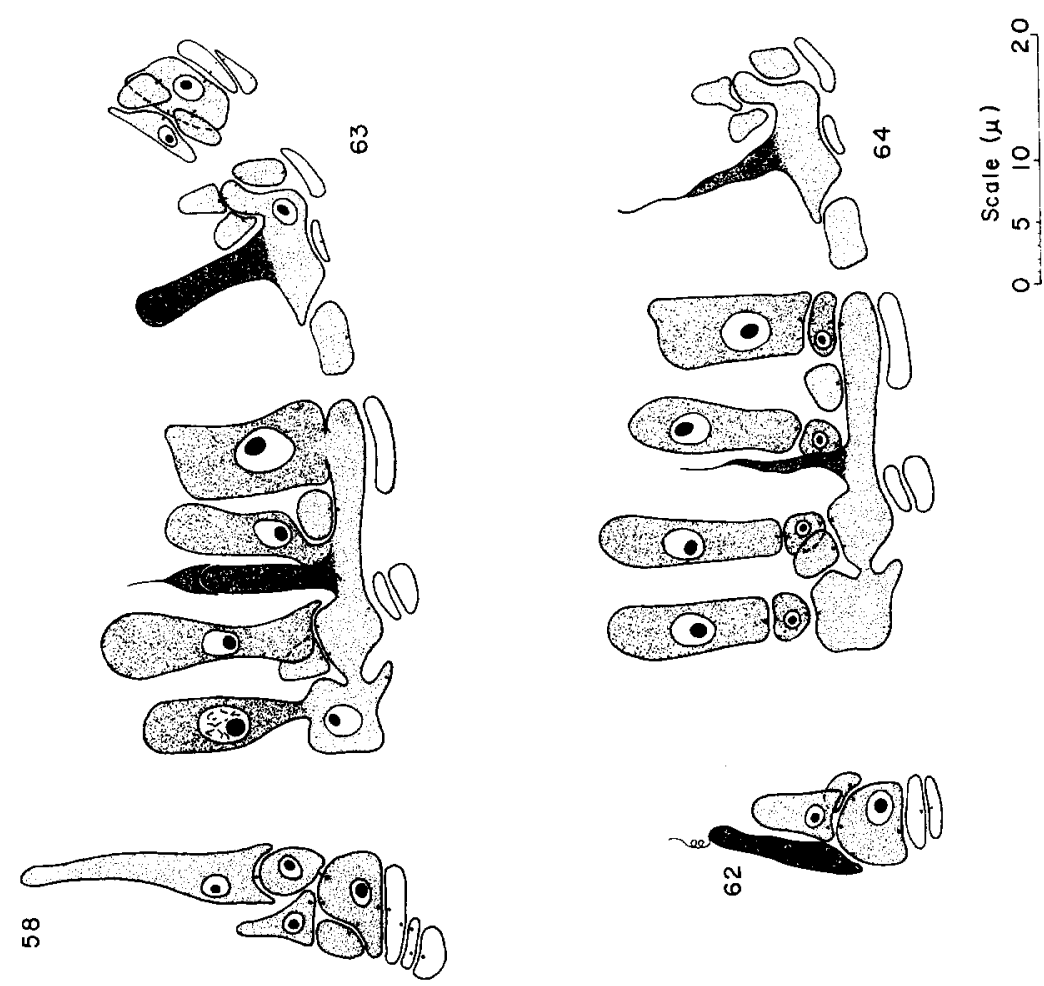

is

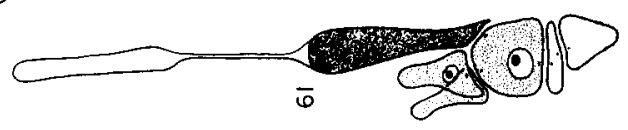
0.00000
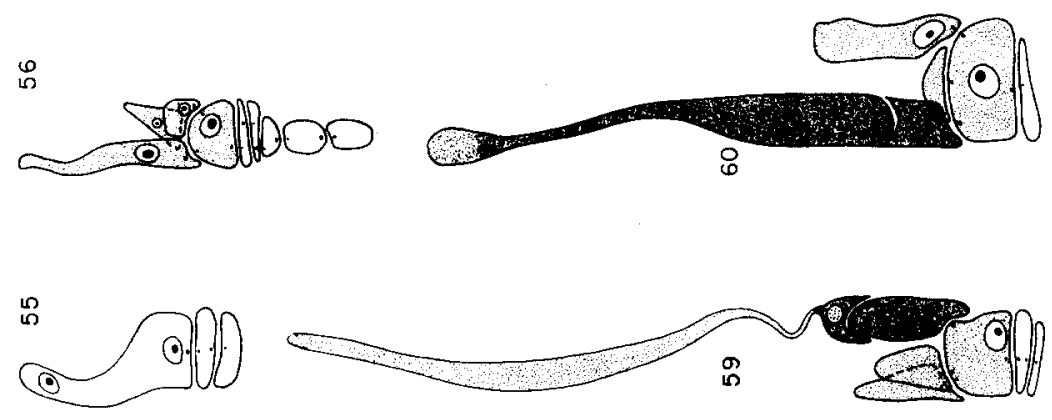
1900 - Die Lithothamnien von Helgoland. Wiss. Meeresuntersuch. (Abt. Helgoland). N.F. 4: 63-82, pl. 2.

Howe, M. A. - 1927 - Hudson Bay Algae. Rep. Canadian Arctic Exped. 1913-1918, 4 (Botany): 18-29.

Johnson, J. H. - 1961 - Limestone Building Algae and Algal Limestones. $\mathrm{xi}+297$ pp., 139 pls., 14 tables. Boulder, Colorado.

KJellman, F. R. - 1883 - The algae of the Arctic Sea. K. Svensk. Vetensk. Akad. Handl., 20 (5): 1-349, 31 pls.

KylıN, H. - 1907 - Studien über die Algenflora der Schwedischen Westküste. Akad. Abhandl. 287 pp., 7 pls. Upsala. 1956 - Die Gattungen der Rhodophyceen. xv + 673 pp., 458 figs. Lund.

Lemorne, M. - 1911 - Structure anatomique des Mélobésiées. Application à la classification. Ann. Inst. Oceanogr., 2 (2): 1-213, 105 figs., 5 pls., 3 folding tables.

LUND, S. - 1959 - The marine algae of east Greenland I., Taxonomic Part. Meddel. om Grøn., 156 (1): 247 pp., 42 figs.

MASAKI, T. \& TokIDA, J. - 1961 - Studies on the Melobesiodeae of Japan. V. Bull. Fac. Fish., Hokkaido Univ., 12 (3): 161-165, pls. 1-4.

Mason, L. R. - 1953 - The crustaceous coralline algae of the Pacific coast of the United States, Canada and Alaska. Univ. Calif. Publ. Bot., 26 (4): 313-390, pls. 27-46.

Myers, A., Preston, R. D. \& Ripley, G. W. - 1959 - An electron microscope investigation into the structure of the Floridean pit. Ann. Bot., 23: $257-260$.

Rosenvinge, L. K. - 1917 - The marine algae of Denmark. Contributions to their natural history. Part II. Rhodophyceae II. (Cryptonemiales). K. Danske Vidensk. Selsk. Skr., ser. 7, Naturv.-Math. 7 (2): 155-283, figs. 74-201, pls. 3, 4 .

SUNESON, S - 1943 - The structure, life-history and taxonomy of the Swedish Corallinaceae. Lunds Univ. Arsskr., N.F., Avd. 2, 39 (9): 66 pp., 26 figs., 9 pls.

- 1950 - The cytology of the bispore formation in two species of Lithophyllum and the significance of the bispores in the Corallinaceae. Bot. Not., 1950: 429-450, 8 figs.

TAYLOR, W. R. - 1937 - 1962 - Marine Algae of the Northeastern Coast of North America. Univ. Mich. Stud., Sci. Ser. 13. vii +427 pp., 60 pls. Ann Arbor. (revised, 1957, reprinted, 1962).

TRITES, R. W. - 1962 - Temperature and salinity in the Quoddy region of the Bay of Fundy. F. Fish. Res. Bd. Canada, 19 (5): 975-978, 2 figs. 